\title{
WHAT CAUSED THE ASIAN CURRENCY AND FINANCIAL CRISIS? \\ PART I: A MACROECONOMIC OVERVIEW
}

\author{
Giancarlo Corsetti \\ Paolo Pesenti \\ Nouriel Roubini
}

Working Paper 6833

http://www.nber.org/papers/w6833

\author{
NATIONAL BUREAU OF ECONOMIC RESEARCH \\ 1050 Massachusetts Avenue \\ Cambridge, MA 02138 \\ December 1998
}

We thank Ignazio Visco and seminar participants at the NBER IFM Program Meeting, March 1998, the CEPR-World Bank Conference on "Financial Crises: Contagion and Market Volatility," May 1998, the University of Washington, and the Bank of Italy for helpful comments on the earlier drafts of this paper. We also thank Michele Cavallo, Scott Nicholson, and Andrew Tiffin for excellent research assistance. Corsetti acknowledges financial support from MURST. The views expressed here are those of the author and do not reflect those of the National Bureau of Economic Research, the Federal Reserve Bank of New York, or any other institution with which the authors are affiliated.

(C) 1998 by Giancarlo Corsetti, Paolo Pesenti, and Nouriel Roubini. All rights reserved. Short sections of text, not to exceed two paragraphs, may be quoted without explicit permission provided that full credit, including $(\mathcal{C}$ notice, is given to the source. 
What Caused the Asian Currency and Financial Crisis?

Part I: A Macroeconomic Overview

Giancarlo Corsetti, Paolo Pesenti, and Nouriel Roubini

NBER Working Paper No. 6833

December 1998

JEL No. F31, F33, F34, F36, G15, G18

\section{ABSTRACT}

The paper explores the view that the Asian currency and financial crises in 1997 and 1998 reflected structural and policy distortions in the countries of the region, even if market overreaction and herding caused the plunge of exchange rates, asset prices, and economic activity to be more severe than warranted by the initial weak economic conditions. The first part of the paper provides an overview of economic fundamentals in Asia on the eve of the crisis, with emphasis on current account imbalances, quantity and quality of financial 'overlending,' banking problems, and composition, maturity and size of capital inflows.

Giancarlo Corsetti

Department of Economics

Yale University

18 Hillhouse Av.

New Haven, CT 06520

corsetti@econ.yale.edu

Nouriel Roubini

Department of Economics

Stern School of Business, MEC 7-83

New York University

44 West 4th Street

New York, NY 10012

and NBER

nroubini@stern.nyu.edu
Paolo Pesenti

Federal Reserve Bank of New York

International Research Function

33 Liberty St.

New York, NY 10045

and NBER

paolo.pesenti@ny.frb.org 


\section{Introduction}

What were the causes of the Asian economic, currency and financial crises of 1997-98? Two main hypotheses and interpretations have emerged in the aftermath of the crisis. According to one view, sudden shifts in market expectations and confidence were the key sources of the initial financial turmoil, its propagation over time and regional contagion. While the macroeconomic performance of some countries had worsened in the mid 1990s, the extent and depth of the 1997-98 crisis should not be attributed to a deterioration in fundamentals, but rather to panic on the part of domestic and international investors, somewhat reinforced by the faulty policy response of the International Monetary Fund (IMF) and the international financial community. ${ }^{1}$

According to the other view - advanced in this paper - the crisis reflected structural and policy distortions in the countries of the region. Fundamental imbalances triggered the currency and financial crisis in 1997, even if, once the crisis started, market overreaction and herding caused the plunge of exchange rates, asset prices and economic activity to be more severe than warranted by the initial weak economic conditions. A synthetic overview of our interpretation is provided in section 2, while sections 3-5 present a systematic assessment of the sources of economic tension at the root of the Asian crisis. This is based on the analysis of the available empirical evidence for the following countries: South Korea, Indonesia, Malaysia, Philippines, Thailand, Singapore, Hong Kong, China and Taiwan. Macroeconomic imbalances in these countries are assessed within a broad overview of structural factors: current account deficits and foreign indebtedness, growth and inflation rates, savings and investment ratios, budget deficits, real exchange rates, foreign reserves, corporate sector investment, measures of debt and profitability, indexes of excessive bank lending, indicators of credit growth and financial fragility, monetary stances, debt-service ratios, dynamics and composition of capital inflows and outflows, and political instability.

The rest of the paper is structured as follows. Section 6 presents a reconstruction of the Asian meltdown, from the period leading to the crisis to its eruption in 1997, and discusses policy responses, contagion effects, and the role of Japan. In section 7 we provide an overview of the debate on policy strategies to recover from the crisis, with particular emphasis on the role played by the IMF. Section 8 singles out the key points in the current debate

\footnotetext{
${ }^{1}$ See Radelet and Sachs (1998) for the most comprehensive exposition of this view.
} 
about the reform of the international financial system and the desirability of free capital mobility. Section 9 focuses on the most recent evolution of the Asian meltdown into a global turmoil in the summer of 1998. The final section outlines a few open issues in assessing the implications of the crises. $^{2}$

\section{At the root of the Asian crisis}

Central to a full understanding of the roots of the Asian crisis is the multifaceted evidence on the structure of incentives under which the corporate and financial sectors operated in the region, in the context of regulatory inadequacies and close links between public and private institutions. ${ }^{3}$ The moral hazard problem in Asia magnified the financial vulnerability of the region during the process of financial markets liberalization in the 1990s, exposing its fragility vis-à-vis the macroeconomic and financial shocks that occurred in the period 1995-1997. The problem exhibited three different, yet strictly interrelated dimensions at the corporate, financial, and international level. ${ }^{4}$

At the corporate level, political pressures to maintain high rates of economic growth had led to a long tradition of public guarantees to private projects, some of which were effectively undertaken under government control, directly subsidized, or supported by policies of directed credit to favored firms and/or industries. ${ }^{5}$ Even in the absence of explicit promises of 'bail-out', the production plans and strategies of the corporate sector largely overlooked costs and riskiness of the underlying investment projects. ${ }^{6}$ With financial and industrial policy enmeshed within a widespread business sector network of personal and political favoritism, and with governments that appeared willing to intervene in favor of troubled firms, markets operated

\footnotetext{
${ }^{2}$ The first part of the paper includes sections 1-5 and tables 1-38. The second part of the paper includes sections 6-10, table 39, and references.

${ }^{3}$ This section is based on Corsetti, Pesenti and Roubini (1998). A partial list of recent studies providing empirical evidence on the Asian crisis includes Alba et al. (1998), Dornbusch (1998 a), Feldstein (1998), Goldstein (1998), IMF (1998), and Radelet and Sachs (1998). A large number of contributions on the crisis are available online on Nouriel Roubini's Asian Crisis Homepage at www.stern.nyu.edu/ nroubini/asia/AsiaHomepage.html.

${ }^{4}$ The role of moral hazard in the onset of the Asian crisis has been stressed by a number of authors. See e.g. Krugman (1998 a), Greenspan (1998), Fischer (1998 b).

${ }^{5} \mathrm{IMF}(1997)$.

${ }^{6}$ See Pomerleano (1998) for a thorough assessment of the corporate roots of the financial crisis in Asia.
} 
under the impression that the return on investment was somewhat 'insured' against adverse shocks.

Such pressures and beliefs represented the underpinnings of a sustained process of capital accumulation, ${ }^{7}$ resulting into persistent and sizable current account deficits. ${ }^{8}$ While common wisdom holds that borrowing from abroad to finance domestic investment should not raise concerns about external solvency - it could actually be the optimal course of action for undercapitalized economies with good investment opportunities — the evidence for the Asian countries in the mid-1990s highlights that the profitability of new investment projects was low. For instance, in Korea, 20 of the largest 30 conglomerates displayed in 1996 a rate of return on invested capital below the cost of capital. In 1997, before the crisis, as many as 7 of the 30 largest conglomerates could be considered effectively bankrupt. ${ }^{9}$

Investment rates and capital inflows in Asia remained high even after the negative signals sent by the indicators of profitability. In part, this occurred because the interest rate fall in industrial countries (especially in Japan) lowered the cost of capital for firms and motivated large financial flows into the Asian countries. However, the crucial factor underlying the sustained investment rates was the financial side of the moral hazard problem in Asia, leading national banks to borrow excessively from abroad and lend excessively at home. ${ }^{10}$ Financial intermediation played a key role in channelling funds toward projects that were marginal if not outright unprofitable from a social point of view.

The literature has focused on a long list of structural distortions in the pre-crisis Asian financial and banking sectors: lax supervision and weak regulation; low capital adequacy ratios; lack of incentive-compatible deposit insurance schemes; insufficient expertise in the regulatory institutions; distorted incentives for project selection and monitoring; outright corrupt lending practices; non-market criteria of credit allocation, according to a model of relationship banking that emphasizes semi-monopolistic relations between banks and firms, somehow downplaying price signals. All these factors contributed to the build-up of severe weaknesses in the undercapitalized financial system, whose most visible manifestation was eventually a growing share of non-performing loans.

\footnotetext{
${ }^{7}$ See section 3.4.

${ }^{8}$ See section 3.1.

${ }^{9}$ See e.g. OECD (1988) for the analysis of the Korean case.

${ }^{10}$ See section 4 .
} 
The adverse consequences of these distortions were crucially magnified by the rapid process of capital account liberalization and financial market deregulation in the region during the 1990s, which increased the supplyelasticity of funds from abroad. ${ }^{11}$ The extensive liberalization of capital markets was consistent with the policy goal of providing a large supply of low-cost funds to national financial institutions and the domestic corporate sector. The same goal motivated exchange rate policies aimed at reducing the volatility of the domestic currency in terms of the US dollar, thus lowering the risk premium on dollar-denominated debt.

The international dimension of the moral hazard problem hinged upon the behavior of international banks, which over the period leading to the crisis had lent large amounts of funds to the region's domestic intermediaries, with apparent neglect of the standards for sound risk assessment. ${ }^{12}$ Underlying such overlending syndrome may have been the presumption that short-term interbank cross-border liabilities would be effectively guaranteed by either a direct government intervention in favor of the financial debtors, or by an indirect bail-out through IMF support programs. A very large fraction of foreign debt accumulation was in the form of bank-related short-term, unhedged, foreign-currency denominated liabilities: by the end of 1996, a share of short-term liabilities in total liabilities above $50 \%$ was the norm in the region. Moreover, the ratio of short-term external liabilities to foreign reserves - a widely used indicator of financial fragility — was above $100 \%$ in Korea, Indonesia and Thailand. ${ }^{13}$

The core implication of moral hazard is that an adverse shock to profitability does not induce financial intermediaries to be more cautious in lending, and to follow financial strategies reducing the overall riskiness of their portfolios. Quite the opposite, in the face of negative circumstances the anticipation of a future bail-out provides a strong incentive to take on even more risk - that is, as Krugman (1998 a) writes, "to play a game of heads I win, tails the taxpayer loses." In this respect, a number of country-specific and global shocks contributed to severely deteriorate the overall economic outlook in the Asian region, exacerbating the distortions already in place.

In particular, the long period of stagnation of the Japanese economy in the 1990s led to a significant export slowdown from the Asian countries; in

\footnotetext{
${ }^{11}$ See e.g. McKinnon and Pill (1996).

${ }^{12}$ See e.g. Stiglitz (1998).

${ }^{13}$ See section 5 .
} 
the months preceding the eruption of the crisis, the hopes for a Japanese recovery were shattered by a sudden decline in economic activity in this country. Sector-specific shocks such as the fall in the demand for semiconductors in 1996, and adverse terms of trade fluctuations also contributed to the worsening of the trade balances in the region between 1996 and 1997.

The sharp appreciation of the US dollar relative to the Japanese yen and the European currencies since the second half of 1995 led to deteriorating cost-competitiveness in most Asian countries whose currencies were effectively pegged to the dollar. ${ }^{14}$ Based on standard real exchange rate measures, many Asian currencies appreciated in the 1990s, although the degree of real appreciation was not as large as in previous episodes of currency collapses (such as Mexico in 1994) and the dynamics of the real exchange rate was asymmetric across countries: by 1997 the extent of real appreciation was evident in Malaysia and the Philippines, while in South Korea, Thailand and Indonesia, real exchange rate indicators had not moved significantly relatively to 1990. In general, competitive pressures were enhanced by the increasing weight of China in total export from the region. ${ }^{15}$

As a result of the cumulative effects of the financial and real imbalances considered above, by 1997 the Asian countries appeared quite vulnerable to financial crises, either related to sudden switches in market confidence and sentiment, or driven by deteriorating expectations about the poor state of fundamentals. In 1997, the drop of the real estate and stock markets where sustained speculative trends were in part fueled by foreign capital inflows - led to the emergence of wide losses and outright defaults in the corporate and financial sectors. Policy uncertainty stemming from the lack of

\footnotetext{
${ }^{14}$ Expectations of a monetary contraction in the US in the summer of 1997 may have also played a role in precipitating the crisis.

${ }^{15}$ Whether cost-competitiveness deteriorated in the rest of the region after the $50 \%$ devaluation of the Chinese currency in 1994 is still a matter of debate. The thesis that "a large part of China's recent export success reflects the devaluation that occurred in January 1994" and that this "cheap-currency policy" was "one of the factors provoking the crisis in Southeast Asia" has been espoused in a Financial Times editorial (September 17, 1997) and echoed in the popular press (see for instance The Economist, November 22, 1997, or Business Times, March 17, 1998). Recent studies (IMF (1997), Liu, Noland, Robinson and Wang (1998) and Fernald, Edison and Loungani (1998)) dismiss the thesis on the basis of several factors, most notably the fact that by 1993 about $80 \%$ of Chinese transactions were already settled at the swap market rate, not the official rate, so that the official exchange rate devaluation influenced only about $20 \%$ of the foreign exchange transactions.
} 
commitment to structural reforms by the domestic authorities worsened the overall climate. From the summer of 1997 onward, rapid reversals of financial capital inflows led to the collapse of regional currencies amidst domestic and international investors panic. ${ }^{16}$

\section{Current account imbalances and macroeco- nomic fundamentals}

\subsection{The evidence}

We start our study of the Asian crisis by assessing the evidence on current account imbalances in the region over the 1990s. The potential role of current account deficits as a source of disruptive tensions in the financial markets has been repeatedly emphasized in the literature. ${ }^{17}$ On the anniversary of the Mexican financial crisis, Lawrence Summers, the US Deputy Treasury Secretary, wrote in The Economist that "close attention should be paid to any current account deficit in excess of $5 \%$ of GDP, particularly if it is financed in a way that could lead to rapid reversals." 18 By this standard, a number of countries in our sample provided reasons for concern.

As shown in Tables 1 and 2, several Asian countries whose currencies collapsed in 1997 had experienced somewhat sizable current account deficits in the 1990s. In the two Tables we show two measures of the current account (as a share of GDP), one based on national income account (NIA) and the other based on balance of payments data; in the discussion we will mostly rely on the NIA data. ${ }^{19}$

The two countries with the largest and most persistent current account

\footnotetext{
${ }^{16}$ For a reconstruction of the crisis, see section 6 and IMF (1997) and (1998).

${ }^{17} \mathrm{~A}$ number of recent contributions on financial and balance of payments crises provide a discussion of the issues introduced in this section - among others see Dornbusch, Goldfajn and Valdes (1995), Milesi-Ferretti and Razin (1996a, b, c), Mishkin (1996), Kaminsky, Lizondo and Reinhart (1998) and Roubini and Wachtel (1998). Among recent studies focusing on the large-scale speculative episodes in the 1990s before the Asian crisis, see Eichengreen and Wyplosz (1993) and Buiter, Corsetti and Pesenti (1998a, b) on the European Monetary Systyem crisis of 1992-93, and Sachs, Tornell and Velasco (1996) on the Mexican peso crisis of 1994.

${ }^{18}$ The Economist, Dec.23 1995-Jan.5 1996, pp. 46-48.

${ }^{19}$ While the two series should in principle be equivalent, quantitative differences can arise because of inconsistencies in the data collection processes.
} 
imbalances in our sample were Thailand and Malaysia, both of which experienced deficits for over a decade. Based on NIA data, the current account in Thailand was over $6 \%$ of GDP virtually in each year in the 1990s, and approached $9 \%$ of GDP in 1995 and 1996. Similarly large numbers were observed in Malaysia, where the deficit was above 10\% of GDP in 1993, while slowly falling to $3.7 \%$ of GDP in 1996. The Philippines also experienced long-term imbalances in having a deficit around or above $5 \%$ of GDP for four years and lastingly high in the remaining years.

Indonesia started the decade with a large imbalance (over $4 \%$ of GDP in 1990-91) but the deficit shrank in 1992 and 1993. Later, the current account imbalance widened again, reaching 3-4\% of GDP in 1995-1996. In Korea, the current account deficit was low in the early 1990s (1-3\% of GDP) and virtually negligible in 1993. However, since 1993 the imbalance grew very fast, approaching 5\% of GDP in 1996. As can be seen from Table 3, these current account imbalances stemmed primarily from large trade deficits, with a relatively small role played by net factor payments to the rest of the world.

Of the remaining countries, Hong Kong started the decade with large current account surpluses, averaging over 7\% of GDP between 1990 and 1993. Things significantly worsened after 1993. In 1994 the surplus shrank to $2 \%$ of GDP, and went into a deficit of more than 2\% of GDP in 1995 and 1996. In Singapore, very large current account surpluses were observed throughout the 1990s, averaging about 10\% of GDP in 1990-1993 and increasing to about $16 \%$ of GDP in 1994-96. In China, the current account was in surplus $(1.5 \%$ of GDP) in 1990-92, but turned into a $2 \%$ deficit in 1993. After 1993, the current account experienced a modest surplus averaging 1\% of GDP. Finally, Taiwan's current account was consistently in surplus in the 1990s, with the 1996 figure showing a large surplus of over $4.5 \%$ of GDP.

Data on the current account positions provide some preliminary evidence that the currency crises may have been associated with an external competitiveness problem. In fact, as a group, the countries that came under attack in 1997 appear to have been those with large current account deficits throughout the 1990s; in 1997 the appreciation of the US dollar relative to the currencies of the high-deficit countries Thailand, Malaysia, Philippines, Korea and Indonesia reached $78 \%, 52 \%, 52 \%, 107 \%$ and $151 \%$ respectively.

Instead, countries with smaller deficits or actual surpluses did not suffer comparable depreciations. China had stable currency values in 1997 (a depreciation of $2 \%$ ). The Hong Kong parity against the US dollar was aggressively and successfully defended against heavy attacks during the year. 
While the exchange rates of Singapore and Taiwan were affected by the regional crisis, the rate of depreciation in these two countries - about $18 \%$ over the year - was well below that of the crisis countries. Moreover, the depreciations in Singapore and Taiwan were orderly, and were not characterized by episodes of speculative frenzy and financial panic such as the ones associated with the currency crises in the rest of the region.

In sum, while the correlation between currency depreciation and external imbalances by group of countries in the 1990s need not imply causation, prima facie evidence suggests that current account problems may have played a role in the dynamics of the Asian meltdown.

\subsection{Solvency, resource balance gaps, and sustainability}

Assessing the sustainability of current account imbalances is not an easy task. In fact, no compelling criterion exists to determine when current account deficits - and the resulting accumulation of net foreign labilities - reach 'excessive' proportions, thus triggering devaluation expectations, speculative outflows, and financial crises.

The standard theoretical criterion for assessing current account imbalances is the notion of solvency: a country is solvent to the extent that the discounted value of the expected stock of its foreign debt in the infinitely distant future is non-positive. In other words, a country that is accumulating foreign debt at a rate that is faster than the real cost of borrowing, cannot expect to be able to do so forever.

In practice, the solvency criterion is not particularly stringent, because the intertemporal budget constraint of a country imposes only very mild restrictions on the evolution of a country's current account and foreign debt. Any path of the current account such that the present discounted value of the current and future trade surpluses is equal to the current external debt position is consistent with solvency. A country could run very large and persistent current account deficits and remain solvent, as long as it can generate trade surpluses (of the appropriate size) at some time in the future. ${ }^{20}$

Since the theoretical notion of solvency is rather loose, policy analysts tend to resort to more practical criteria. A popular 'test' of solvency in practical terms is a non-increasing foreign debt to GDP ratio. It can be

\footnotetext{
${ }^{20}$ For an updated textbook treatment of solvency see chapter 2 of Obstfeld and Rogoff (1996).
} 
easily shown that, under the realistic assumption that in the long run the interest rate exceeds the growth rate of output, a stable debt to GDP ratio is a sufficient condition for solvency. Based on this condition, then, the criterion of solvency can be made operational by calculating the so-called 'resource balance gap' - in a country where the debt to GDP ratio is growing, this gap is the difference between the current trade balance and the trade surplus required to stabilize the debt to GDP ratio in the long run. ${ }^{21}$ The gap will be larger for countries with a large trade deficit to GDP ratio, a large debt to GDP ratio, or a large differential between the real interest rate and the growth rate of the economy. ${ }^{22}$

To calculate the 'resource balance gap', one needs to make assumptions about the long-run differential between the real interest rate and the growth rate of the economy. There exists compelling reasons - both at the theoretical and empirical level — to argue that such a differential is positive in a steady state, regardless of whether negative values are observed in the short run. A $1 \%$ differential between the real interest rate and output growth is a conservative but realistic assumption.

On the basis of the above assumptions, the trade balance adjustment required to stabilize the foreign debt to GDP ratio at the 1996 value are shown below. All figures are in percentage of GDP.

\begin{tabular}{|ll|}
\hline Korea & $4.4 \%$ \\
Thailand & $6.9 \%$ \\
Indonesia & $3.3 \%$ \\
Philippines & $6.5 \%$ \\
Malaysia & $2.3 \%$ \\
\hline
\end{tabular}

The table shows that resource gaps were quite large already in 1996. It is

\footnotetext{
${ }^{21}$ To obtain unbiased estimates, the resource balance gap should be computed by considering only the structural component of the current trade deficit. However, in the case of high-growth countries, it is reasonable not to assign a large weight to cyclical factors. In our estimates below, we take the 1996 trade deficit as being entirely structural.

${ }^{22}$ Formally, start from the current account identity $B_{t+1}=(1+r) B_{t}-T_{t}$ (where $B$ is the net debt position of the country and $T$ is the trade balance) and divide both sides by current GDP, denoted $Y_{t}$. Assuming that GDP grows at the constant rate $g$, so that $Y_{t+1} / Y_{t}=1+g$, the previous expression can be rewritten as $(1+g) b_{t+1}=(1+r) b_{t}-\tau_{t}$, where $b=B / Y$ and $\tau=T / Y$. For the debt to GDP ratio to be constant in the long run at some level $b$, the trade balance surplus (as a fraction of GDP) must be equal to $(r-g) b$. The resource balance gap is the difference between the above trade surplus and the currently observed trade balance (both as percentages of GDP).
} 
worth emphasizing that we would obtain even larger figures by increasing the permanent interest rate-growth differential above 1\%, or by using the 1997 figures for foreign debt to GDP. Our calculation is in fact carried out relative to the 1996 (end of the year) stock of foreign debt, rather than the larger 1997 figure - making our estimates of the resource balance gap appropriate to assess the pre-crisis imbalances, but very conservative when applied to the post-crisis scenario, since the 1996 figures do not reflect the significant devaluation-induced increase in the external burden of the countries.

A more thorough assessment of the evidence on current account deficits focuses on the notion of sustainability of the external imbalances. To specify the meaning of 'sustainability' in the context of our analysis, consider a country running a current account deficit and accumulating foreign debt relative to its GDP, so that solvency requires the country to run trade surpluses at some point in the future. We consider a path of current account deficits and foreign debt accumulation sustainable when the reversal in the trade balance consistent with solvency can be expected to materialize without a sharp change in current policies and/or an external crisis. ${ }^{23}$

The notion of sustainability raises complex macroeconomic and politicaleconomy issues in the analysis of external imbalances. For instance, sustainability can be related to both the country's 'willingness to pay', and the creditors 'willingness to lend'. Willingness to pay can become an issue when a country is potentially solvent but, as Milesi-Ferretti and Razin write, "it is not politically feasible to divert output from domestic to external use to service the debt". ${ }^{24}$ Creditors' willingness to lend on current terms is a maintained assumption in the theoretical solvency criterion, but such presumption may not be realistic if, for any reason, foreign creditors come to believe that the country will renege on its liabilities; acting under this presumption, they will require a higher default premium, or stop lending altogether. ${ }^{25}$

\footnotetext{
${ }^{23}$ An external crisis could come in the form of a currency crisis - a run on the central bank's foreign exchange reserves and/or a rapid depreciation of the exchange rate - or a foreign debt crisis - the inability to obtain further international financing, or to meet repayments, or an actual default on debt obligations.

${ }^{24}$ Milesi-Ferretti and Razin (1996a, p. 1).

${ }^{25}$ Since the current account is the sum of the trade balance and net factor incomes and transfers from abroad, sustainability is also affected by the relative weight of these components. For a given level of current account deficit, sustainability may be more problematic if the trade deficit is large, as opposed to large negative flow of net factor payments from abroad. A trade deficit may indicate structural competitiveness problems, while a large and negative flow of net foreign income represents the historical remnant of
} 
However, rather than providing a unifying theoretical framework for the study of external imbalances, the approach based on the notion of sustainability is primarily focused on the empirical analysis of macroeconomic performances during crisis episodes, in order to determine under which conditions sharp trade balance reversals are more likely to occur. In this light, we now turn to the assessment of current account imbalances in the context of an overview of macroeconomic fundamentals in the Asian region: GDP growth, private and public savings rate, inflation, and the degree of openness.

\subsection{Output growth}

The historical experience of the 1980 debt crisis suggests that there are several practical reasons why large current account deficits may be perceived as sustainable when current and expected economic growth is high. For a given current account deficit to GDP ratio, higher growth rates imply a slower dynamics of the foreign debt to GDP ratio, and enhance the country's ability to service its external debt. In addition, high (actual and expected) GDP growth may reflect sustained capital accumulation rates driven by expectations of high profitability, and high growth might also explain a transitory decline in the saving rate, in anticipation of higher future income. If this is the case, current account imbalances driven by a transitory fall in private savings should not be a concern, since future income growth will lead to increased future savings.

Table 4 presents the growth data in our sample of Asian countries in the 1990s. The overall picture is quite clear: in all countries, GDP growth rates were remarkably high in the 1990s. Growth rates averaging more than $7 \%$ of GDP (sometimes closer to 10\%) were the norm. The exception is the Philippines, where growth rates were low in the early 1990s, but still averaged 5\% after 1994. Only in 1996 did most countries in the region experience a marginal slowdown in growth; for example, the growth rate in Korea fell from $8.9 \%$ of GDP in 1995 to $7.1 \%$ in 1996. Accepting the traditional view that a large current account deficit is likely to be sustainable when growth is high, the Asian countries did not appear to have a sustainability problem. The key question, however, is whether or not the traditional view provides reliable indications for the diagnosis of the Asian crisis.

Historical experience suggests in fact a more complex picture in which,

past foreign indebtedness. 
paradoxically, high economic growth may make an economy more vulnerable to a crisis. ${ }^{26}$ For instance, high growth rates may induce overly-optimistic beliefs that the economic expansion will persist unabated in the future. Such expectations can then drive both a consumption and investment boom, as well as large capital inflows that make it easy to finance the increasing demand. In such circumstances, an external shock that leads to a sudden change in expectations can cause a rapid reversal of capital flows and trigger a currency crash. ${ }^{27}$

In the specific case of the 1997-98 crisis, this argument is strictly related to the debate on the causes of the Asian 'economic miracle'. The issue in that debate is the extent to which output growth in Asia was due to total factor productivity (TFP) growth, as opposed to growth in the availability of inputs, reflecting increasing rates of investment and labor participation in the region. Krugman (1994) popularized the controversial view — originally advanced by Young (1992) — that the contribution of TFP to output growth in Asia was less sizable than commonly believed, suggesting that the very rapid growth that Asia experienced in the past decades could not be sustainable in the long run, as employment growth and investment were eventually bound to decline.

Such an interpretive scheme cannot explain the sudden crash of the Asian economies in 1997, since it only predicts a slowdown of growth. Yet, it does point out that, in the period leading up to the crisis, extrapolating the high rates of growth of the 1990 s into the future was not necessarily warranted by fundamentals. To the extent that savings and investment decisions were based on unrealistic expectations about long-run output perspectives, the observed high rates of growth may have contributed to downplaying the riskiness and costs of a strategy of excessive reliance on foreign capital and current account imbalances.

\subsection{Investment rates, efficiency and profitability}

Other criteria of current account sustainability focus on the intertemporal decisions underlying a current account deficit. Since the current account is

\footnotetext{
${ }^{26}$ The traditional view does not fit, for instance, the cases of Chile in 1979-81 and Mexico in 1977-81, whereas average real GDP growth rates in the years preceding the crisis were above $7 \%$.

${ }^{27}$ Rigobon (1998) develops a model where excessive optimism leads to excessive capital inflows in 'good' times and rapid reversals and market overreaction in 'bad' times.
} 
equal to the difference between national saving and investment, a deficit can emerge from either a fall in saving or an increase in investment. Conventional wisdom holds that borrowing from abroad is less 'dangerous' for sustainability if it finances new investment (leading to increased productive capacity and to higher future export receipts) rather than consumption (which implies lower saving). For these reasons, a current account deficit that is accompanied by a fall in saving rates is regarded as more problematic than a deficit accompanied by rising investment rates.

Underlying such 'conventional' conclusions, however, is the implicit assumption that the return on investment is at least as high as the cost of the borrowed funds. Also implicit is the assumption that high investment rates contribute to the enhancement of productive capacity in the traded sector. If the investment boom is confined to the non-traded sector (commercial and residential construction, as well as inward-oriented services), in terms of sustainability analysis the contribution of such investment projects to future trade surpluses - thus to the ability of the country to repay its external debt obligations - is limited to their indirect impact on the productivity of the traded sector. The two 'implicit' assumptions above need not hold in the Asian case.

Evidence on investment rates in Asian countries is shown in Table 5 (corresponding data on saving ratios are presented below). Unlike the Latin American countries that experienced currency and financial crises in the recent past, the Asian countries were characterized by very high rates of investment throughout the 1990s. In most countries these rates were well above $30 \%$ of GDP (and in some cases above $40 \%$ of GDP), with the exceptions of the Philippines and Taiwan, that show rates in the $20-25 \%$ range.

One may of course wonder whether aggregate measures of investment above $40 \%$ of GDP truly represented the real magnitude of productive capital accumulation in these economies. On the basis of anecdotal evidence, it has been argued in fact that the official investment rate measures were likely to be upward biased, as several forms of 'investment' in the Asian economies may have simply been a disguised form of consumption. ${ }^{28}$

More generally, there are several reasons why such high investment rates

\footnotetext{
${ }^{28}$ As suggested by the head of research in a Thai brokerage house: "there is in practice no clear divide between investment and consumption in Thailand... For example, one very clear example of overinvestment has been in five-star or equivalent hotels. Every family business empire feels it has to have one, and to out-do its friends or enemies in outfitting it luxuriously. This is just an aspect of that I call 'conspicuous investment'."
} 
should have been regarded with concern in regards to current account sustainability. Evidence on the profitability of the investment projects is provided by a standard measure of investment efficiency, the ICOR or 'incremental capital output ratio' defined as the ratio between the investment rate and the rate of output growth. As bad investments might have been concentrated in some sectors of the economy (such as real estate and some manufacturing sectors), an aggregate measure such as the ICOR does not provide information about the variability of rates of return across sectors. But as a measure of overall investment efficiency, its level and changes over time provide a broad estimate of the productivity of capital.

Table 6 presents two sets of data, one for the 1987-1992 period and the other for the 1993-1996 period. The data for both periods suggest that investment efficiency is generally high in the Asian region. However, with the exception of Indonesia and the Philippines, the ICOR had increased sharply in the 1993-96 period relative to the 1987-1992, suggesting that the efficiency of investments was already falling in the four years prior to the 1997 crisis.

In the case of Korea, evidence of low profitability is also available at the firm level. In this country, the 1997 crisis was primarily triggered by a series of bankruptcies of large conglomerates (chaebols) who had borrowed heavily to finance their investment projects. In 1997, and before the currency crisis hit Korea, as many as seven of the top 30 conglomerates could be considered effectively bankrupt. ${ }^{29}$ The extent of the financial problems of the chaebols is presented in Table 7 - outlining the assets, liabilities, sales, net profits and debt-equity ratios for the top 30 chaebols at the end of 1996 . The table shows that the average debt-equity ratio for the 30 chaebols was $333 \%$ (the comparable figure for the US is close to 100\%). Those chaebols that went bankrupt or had severe financial problems in 1997, tended to have even larger debt-equity ratios. In the case of Sammi (bankrupt in January), the ratio was a staggering $3,245 \%$, while in the case of the Jinro group the ratio was $8,598 \%$. The table also shows that profitability, as measured by net profits, was very low (or outright negative in the case of 13 out of 30 companies).

Table 8 shows the return on invested capital (ROIC) in the 1992-96 period

\footnotetext{
${ }^{29}$ See OECD (1998). The shaky conditions of Korean groups had been exhaustively analyzed by the specialized press before the eruption of the crisis: as an example, see "20 of top 30 groups show poor management performance," The Korea Herald, October 7, 1997. We thank Seung Jung Lee for surveying the available information.
} 
for five of the bankrupt firms. ${ }^{30}$ With a prime rate in local currency that before the crisis was as high as $12 \%$, the ROIC for these firms was well below the cost of capital in the 1992-96 period (with the exception of Kia) as well as in 1996 (without exceptions). In the cases of Hanbo, Sammi and Jinro, the first chaebols to collapse in 1997, the ROIC at the end of 1996 was as low as $1.7 \%, 3.2 \%$ and $1.9 \%$ respectively. ${ }^{31}$ Figures on profitability - over the $1990 \mathrm{~s}$ - were particularly low for the conglomerates that went bankrupt in 199\%, and according to evidence available during the first half of 1997, the ROIC was below the cost of capital for 20 out of the top 30 chaebols. Evidence on the low profitability of investment was also provided by the Interest Coverage Rate (ICR) — which compares cash flow earned with interest payments due over a particular period: 11 out of the 30 top chaebols had an ICR below 1, meaning that earnings were below interest payments. ${ }^{32}$

In Korea, most investment projects by the chaebols were concentrated in the manufacturing sector. However, in other countries overinvestment and overcapacity problems were concentrated instead in the non-traded sector. The low profitability of these investment projects can be assessed by looking at the data on Central Business District vacancy rates and rental yields presented in Table 9. As the table shows, before the onset of the crisis, rental yields on office buildings were already quite low, reflecting the very high prices of real estate. In mid 1997, they were as low as 3.5\% in Hong Kong and $3.9 \%$ in Singapore. The rental yields for other countries were higher but the figures for June 1997 are partly artificial, because they are based on pre-downturn expected vacancy rates. ${ }^{33}$

$>$ From a different viewpoint, evidence consistent with speculative overinvestment in land and real estate is provided by data on stock market prices, which in many countries rose more rapidly in the property sector than in the other sectors over the 1990-96 period. Similarly, when national stock markets

\footnotetext{
${ }^{30}$ Of the chaebols included in Table 8, only Hanbo and Dainong were not among the top 30 considered in Table 7.

${ }^{31}$ OECD (1998) points out that the return on capital of industrial companies in Korea were below the pre-tax cost of debt between 1987 and 1995. Data disaggregated by sector show that only the steel industry realized profits in excess of debt charges in the 1993-1995 period.

${ }^{32}$ See "Essence of Korean corporate crisis", Korean Economic Briefing, October 231997. For a recent analysis of poor corporate performances in the pre-crisis Asian region see Pomerleano (1998).

${ }^{33}$ In 1997 the highest vacancy rates were in Bangkok (15\%), Jakarta (10\%) and Shanghai $(30 \%)$.
} 
collapsed in 1997, ${ }^{34}$ the percentage drop was much sharper in the property sector than for the overall market.

Data on overall stock market indices in local currency are presented in Table 10, while Table 11 presents similar data for stock price indices for the property/real estate sector — all data are end-of-year figures. Between 1990 and 1993, the Thai stock market rose by $175 \%$ (395\% for the property sector) but then lost 51\% (73\% for the property sector) of its value between 1993 and the end of 1996. In Malaysia, stock prices rose by $145 \%$ (160\% for the property sector) between 1990 and the end of 1996. In the Philippines, the stock market rose by 386\% (271\% for the property sector) between 1990 and 1996. In Hong Kong, stock prices increased by $344 \%$ ( $423 \%$ for the property sector), while in Singapore they rose by $92 \%$ (181\% for the property sector), and in Taiwan they rose by $53 \%$ (-9,8\% for the hotel sector). In Indonesia, the market rose by $53 \%$ between 1990 and 1996, a period characterized by large volatility in stock prices. Finally, in Korea, stock prices rose by $47 \%$ between 1990 and 1994 but then dropped sharply, falling 36\% by the end of 1996 as the 1995/96 economic slowdown hit corporate profitability.

\subsection{Private and public savings}

In parallel with the assessment of investment rates, the analysis of the dynamics of private and public savings can shed light on the sustainability of the underlying current account imbalances. A fall in national savings caused by lower public savings (a higher budget deficit) is typically seen as more disruptive than a fall in private savings. ${ }^{35}$ The conventional underpinning of this view is that a fall in private savings is more likely to be a transitory phenomenon, ${ }^{36}$ while an increase in public sector deficits often represents a

\footnotetext{
${ }^{34}$ Note that in several countries stock prices had already peaked before 1996 and stock markets were falling even before the 1997 crash.

${ }^{35}$ It is worth recalling that, at a theoretical level, budget deficits can cause current account deficits even in economies in which Ricadian equivalence holds. For instance, it is well known that, in a Ricardian world, a transitory increase in government spending leads to both a budget deficit and a current account deficit. When taxes are distortionary and the government follows a tax-smoothing rule, transitory negative output shocks will also cause both a budget deficit and a current account deficit.

${ }^{36} \mathrm{~A}$ transitory fall in private savings (corresponding to a transitory increase in consumption) is determined by expectations of higher future GDP growth raising permanent income. The transitory fall in savings today will be offset by higher savings in the future, when the anticipated increase in income actually materializes.
} 
persistent change which results in an irreversible build-up of foreign debt.

The issue of understanding the role of public vs. private saving in a current account crisis is however far from settled, as there are historical examples that are clearly at odds with the interpretive pattern just described. For example, in the Chilean 1977-81 case, a crisis occurred in spite of the fact that the fiscal balance was in surplus. In the more recent Mexican episode, the deterioration of the current account in the years preceding the 1994 crisis was largely due to a fall in private savings and a boom in private consumption. Such behavior was fueled by overly-optimistic expectations about future growth, in an environment in which the liberalization of domestic capital markets loosened liquidity constraints - suggesting that current account deficits driven by a fall in private saving rates may be a matter of concern even if such a fall can be interpreted as the result of rational consumption/saving decisions.

Data on saving rates in Asia are reported in Table 12, and somewhat represent the mirror of the investment rates in Table 5. Asian countries were characterized by very high savings rates throughout the 1990 s - in many cases above $30 \%$ of GDP and in some cases above $40 \%$. The lowest rates are recorded for the Philippines, where the saving rate fluctuated between $17 \%$ and $20 \%$, Indonesia, where the saving rate fell below $30 \%$ (to a $28 \%$ average) after 1992, and Malaysia, where the saving rate was below $30 \%$ until 1993. Looking at the data before the crisis, there is little evidence of public dissaving - so that the current account imbalances do not appear to be the result of increased public sector deficits. Table 13 shows that in most countries the fiscal balance of the central government was either in surplus or a small deficit. In 1996, only China and Taiwan displayed a central government deficit (about 1\% of GDP).

The absence of fiscal imbalances in the years preceding the crisis, however, should not be interpreted as pervasive evidence against the fiscal roots of the Asian crisis. As we document below, and we model formally in Corsetti, Pesenti and Roubini (1998), the pre-crisis years were a period of excessive credit growth in the banking system, leading to a large stock of non-performing loans and the eventual collapse of several financial institutions. By early 1998, the overall cost of 'cleaning up the financial sector' — as put by the First Deputy Managing Director of the IMF Stanley Fischer — was realistically expected to amount to 15 percent of GDP for several Asian economies. ${ }^{37}$

\footnotetext{
${ }^{37}$ Fischer (1998 b). By September 1998, the most recent unofficial estimates of the
} 
Ultimately, the restructuring of the financial sector poses a severe burden on the fiscal balances of the affected countries. In terms of our analysis of current account sustainability, such costs represented an implicit fiscal liability for the Asian countries. Such a liability was not reflected by data on public deficits until the eruption of the crisis, but affected the sustainability of the pre-crisis current account imbalances since it contributed to generate expectations of drastic policy changes (a fiscal reform required to finance the costs of financial bail-outs) or currency devaluations (as a result of higher recourse to seigniorage revenues).

\subsection{Inflation}

Inflation is also important in the analysis of current account and external debt sustainability. When currency values are fixed or semi-fixed, and domestic inflation is above foreign inflation, a real currency appreciation leads to decreasing cost-competitiveness, eventually undermining the credibility of the peg. In particular, high inflation rates may signal poor macroeconomic policy and/or sizable fiscal imbalances, generating the need for seigniorage revenue. In either case, high inflation signals that the fixed or semi-fixed exchange rate regime is potentially exposed to speculative attacks.

Table 14 presents the data on inflation in our sample of Asian countries in the 1990s. The overall picture is quite clear: in all countries, inflation rates were relatively low in the 1990s. The only exceptions were the Philippines where inflation was close to $20 \%$ in $1990-1991$ (but falling to $8 \%$ by 1996), Hong Kong with an inflation rate of $11 \%$ in 1991 but falling to $6 \%$ by 1996 and China where the inflation rate was above 10\% in the 1993-95 period (averaging 18\% per year) but falling to 8\% in 1996 and to 3\% in 1997.

However, in terms of our sustainability analysis the picture is considerably more complex. The banking and financial sector problems experienced by several Asian countries over the 1990s raised considerable doubts about their ability to keep inflation low in the near future. Specifically, these doubts were related to the possibility that the consequences of the banking sector bail-outs might prompt an increasing use of seigniorage, and would require infusions of liquidity to prevent systemic runs. For these reasons, the nominal depreciations of Asian currencies in 1997 were consistent with the expected inflationary consequences of banking and financial bail-outs. Ex-post data

financial restructuring costs have increased to the $20-30 \%$ range. 
seem to confirm this view: injections of liquidity into the banking system have occurred in several countries, such as Indonesia and Malaysia, and inflationary pressures have emerged in Asia, either explicitly (Indonesia) or masked by tight price controls (Malaysia).

\subsection{Openness}

Economies that are relatively open are considered less likely to face sustainability problems, for two reasons. First, a large export sector (generating foreign currency receipts) strengthens the country's ability to service its debt obligation. Second, the economic and political costs of a crisis are relatively large, as the interdependence of the economy with the rest of the world is high. Since the costs of a cut-off from international capital markets and disrupted trade credit may be quite severe, the country is more likely to be willing to honor its liabilities. Yet, greater openness also makes the country more vulnerable to terms of trade shocks and to restrictive trade policies in other countries.

Table 15 reports the ratio of the average of exports and imports to GDP, as measures of the degree of openness of the countries under study. As the table shows, most Asian countries were considerably open. The degree of openness is the lowest in Indonesia (around 26-27\%). The measures are in the $30-40 \%$ range in Korea, the Philippines and Thailand, close to $50 \%$ in Taiwan, above $80 \%$ in Malaysia, and above $100 \%$ in the city-states of Hong Kong and Singapore. It is worth recalling here that significant negative terms of trade shocks were experienced by several East Asian countries in 1996 with the fall in price of some of their main exports (semi-conductors and other manufactured goods).

\subsection{Real exchange rate appreciation}

Virtually all analyses of crisis episodes emphasize that a significant real exchange rate appreciation may be associated with a loss of competitiveness and a structural worsening of the trade balance, thus jeopardizing the sustainability of the current account. What was the role of real exchange rate fluctuations in the aggregate demand boom and external balance deterioration observed in the Asian countries prior to the crisis? To what extent were the current imbalances caused by a misalignment in exchange rates? The evidence is somewhat mixed, as the degree of real appreciation over the $1990 \mathrm{~s}$ 
differed widely across Asian countries.

Data on nominal exchange rates in the 1990s are presented in Table 16. In Malaysia, the currency moved in a $10 \%$ range of 2.7 to 2.5 ringgit to the US dollar for most of the period spanned by 1990 and the beginning of 1997. In Thailand the baht was effectively fixed between 25.2 to 25.6 to the dollar from 1990 until 1997. And in the Philippines during 1990-95, the peso/dollar rate fluctuated between 24 and 28, but was effectively fixed at 26.2 from the spring of 1995 until the beginning of 1997.

Other countries followed a somewhat more flexible exchange rate policy. In Korea, the won depreciated in nominal terms between 1990 and the beginning of 1993 (from 700 to almost 800 won per dollar). Between 1993 and mid 1996, it was quoted within a very narrow range of 800 to 770 , and then it depreciated again, reaching 884 won per US dollar by the end of 1996 . The Indonesian policy can be described as real exchange rate targeting, with the nominal rupiah/dollar rate falling from 1900 in 1990 to 2400 by the beginning of 1997.

Taiwan also followed a policy of real exchange rate targeting, allowing its currency to fall from a rate of 24 New Taiwan dollars per US dollar in 1990 to a rate of 27.8 by the end of 1996 . And in Singapore, the currency actually appreciated in nominal terms, from a 1990 rate of 1.7 to a rate of 1.4 by the end of 1996. Finally, in China where inflation was in double figures in the early 1990s, the currency was allowed to depreciate modestly between 1990 and 1993 but was drastically devalued by around 50\% in 1994 (substantially bridging the gap between the official rate and the swap market rate, at which about $80 \%$ of Chinese transactions were settled). Since then, the currency has remained stable with a slight drift towards nominal appreciation.

Table 17 presents the data on the real exchange rate of the Asian countries in our sample. ${ }^{38}$ Taking 1990 as the base year, we observe that by the spring of 1997 the real exchange rate had appreciated by $19 \%$ in Malaysia, $23 \%$ in the Philippines, $12 \%$ in Thailand, $8 \%$ in Indonesia, $18 \%$ in Singapore, and $30 \%$ in Hong Kong. In Korea and Taiwan, the currency depreciated in real terms (respectively by $14 \%$ and $10 \%$ ). This suggests that with the important exception of Korea, all the currencies that crashed in 1997 had experienced a real appreciation. ${ }^{39}$

\footnotetext{
${ }^{38}$ The source of these data is the JP Morgan RER series, that goes back to 1970; the base year for the trade weights is 1990 .

${ }^{39}$ The magnitude of the real appreciation differs across indicators and sources. The data computed by Radelet and Sachs (1998) suggest a real appreciation larger than the
} 
It should be stressed that in several countries, a large part of the real appreciation occurred after 1995, in parallel with the strengthening of the US dollar. ${ }^{40}$ In fact, the choice of the exchange rate regime against the US dollar was a key factor in the observed real exchange rate appreciation. ${ }^{41}$ Countries with more rigid policy rules experienced a much larger real appreciation. Conversely, countries such as Korea and Taiwan that followed a more flexible exchange rate regime experienced a real depreciation. Note that Indonesia, which followed a regime closer to real exchange rate targeting, faced a smaller real appreciation than Thailand, Malaysia, Hong Kong and the Philippines - countries that focused more closely on exchange rate stability.

The data also suggest that, in general, an exchange rate appreciation was correlated with a worsening of the current account - countries with appreciating currencies generally experienced a larger deterioration of the current account, while countries such as China and Taiwan that had experienced a real depreciation exhibited current account surpluses. The decision to maintain a stable currency led to large capital inflows, attracted by favorable interest rate differentials and expectations of low exchange rate risk. The resulting strong real appreciation helped build the region's large and growing current account imbalances. The exception was, once again, Korea, which displayed current account deficits together with a currency that depreciated in real terms over the 1990s.

Is it possible that the observed movements in relative prices reflected a change in the equilibrium real exchange rate, rather than a misalignment? First, high rates of productivity in the tradables sector relative to the nontraded sectors may lead to real appreciation, along the lines of the Balassa-

one presented in this paper. Similarly, the data computed by Merril Lynch show a larger degree of real appreciation, especially after 1995. Conversely Chinn (1998) estimates a structural model of real exchange rate determination and finds a lower degree of real appreciation.

${ }^{40}$ The US dollar appreciated sharply in the months leading to the crisis. Between 1991 and 1995, the US dollar had followed a downward nominal trend relative to the yen and the mark, reaching a low of 80 yen per dollar in the spring of 1995. After the spring of 1995, the dollar started to appreciate very rapidly: the yen/dollar rate appreciated $56 \%$ between the spring of 1995 and the summer of 1997.

${ }^{41}$ Only Hong Kong had actually a currency board with the parity tied to that of the US dollar. Other countries were formally pegging their exchange rate to a basket of currencies; however, the effective weight of the US dollar in the basket was so high that their policies could be characterized as an implicit peg to the US currency. 
Samuelson model. Second, even when the Balassa-Samuelson argument does not apply, models of exchange rate-based stabilization programs suggest that the typical investment and consumption booms that follow a successful inflation stabilization program may lead to both an increase in the relative price of non-traded to traded goods (a real appreciation), and a worsening of the current account — see Rebelo and Vegh (1995) and Calvo and Vegh (1998). ${ }^{42}$

The question of whether the real appreciation observed in Asia was the result of a misaligned exchange rate or an equilibrium real appreciation is open, but there are reasons to be skeptical of explanations that rely too much on a change in the equilibrium exchange rate. First, evidence for a Balassa-Samuelson effect in Asia is slim. Second, the Asian countries do not fit the story of an exchange rate-based stabilization starting from high inflation. One of the key reasons why many Asian countries pursued a policy of an effective peg against the dollar was to facilitate external financing of domestic projects. The cost of borrowing fell because a credible peg led to a reduction of the currency risk premium charged by international investors. This policy was consistent with a strategy of sustaining high investment rates, which were supposed to translate into high rates of productivity and output growth. Most crucially, the loss in competitiveness (i.e. the increase in the relative price of exports) experienced by the Asian countries that pegged their currencies to the US dollar was particularly relevant when the value of the dollar soared after mid-1995.

It is worth emphasizing that movements in the real exchange rates are not necessarily dependable measures of changes in external competitiveness, since this can also suffer from shocks that do not translate in a relative price increase. The misalignment of Asian currencies was exacerbated by a number of these shocks. First, the long period of stagnation within the Japanese economy led to a significant slowdown of export growth for its Asian trading partners. Close to the onset of the crisis, the abortive Japanese recovery of 1996 was overshadowed by a decline in activity in 1997, triggered by the introduction of a consumption tax in April 1997. Second, the increasing weight of China in total exports from the region enhanced competitive pressures

\footnotetext{
${ }^{42}$ Strictly speaking, the exchange rate stabilization models presented in the literature do not provide an equilibrium explanation of the stylized facts on real appreciation and current account deficits after a stabilization. Their numerical simulations show that a good fit of the data requires the introduction of some form of price/wage inertia (see Rebelo and Vegh (1995)). But this inertia is consistent with the view that a real appreciation represents a misalignment relative to fundamental values.
} 
in many Asian countries - an argument that holds regardless of whether such pressures were magnified or not by the devaluation of the Chinese currency in 1994. Third, as mentioned above, sector-specific shocks such as the fall in the demand for semi-conductors in 1996, together with deteriorating terms of trade for several countries in the region, caused a further significant slowdown in export growth in 1996-97. And finally, expectations of a US monetary tightening in the summer of 1997 may have also played a role in precipitating the crisis.

\subsection{Political instability and policy uncertainty}

The threat of a change in regime or a regime that is not committed to sound macroeconomic policies can reduce the willingness of the international financial community to provide current account financing. So a deterioration in expectations about the political and financial environment can contribute to a balance of payments and exchange rate crisis, especially when economic fundamentals are not very comforting. Such shifts in expectations can occur quickly and without warning. Moreover, political instability may lead to larger budget deficits that, in an open economy, may lead to larger current account deficits. ${ }^{43}$

In this regard, there was plenty of political instability in Asia. Focusing on 1997 alone: the cabinet reshuffles, and eventual government collapse in Thailand; the ranting by Malaysian Prime Minister Mahathir against "rogue speculators" and international "morons"; the elections in Indonesia, the tensions, the reiterated bad news about the health of the Indonesian president Suharto, and his policy reversals; the presidential campaign in Korea and the contradictory signals sent by then candidate (and eventually President elect) Kim Dae Jung; the threat of labor unrest in the region; these were all factors that added to the seriousness of the crisis and triggered the domestic and foreign investors' flight.

Throughout the crisis, market expectations reflected and reacted to political and policy uncertainty in the region. The first round of the IMF plans were signed but not seriously implemented by governments. Regardless of whether the initial IMF plans were appropriate, ${ }^{44}$ it is clear that governments

\footnotetext{
${ }^{43}$ For a formal model of how political instability may exacerbate a fiscal and current account deficit, see Corsetti and Roubini (1997). For a systematic study of political influences on macroeconomic policy, see Alesina, Roubini and Cohen (1997).

${ }^{44}$ See the discussion in section 7 .
} 
failed to enforce even the most sensible components of such plans. In Indonesia, a corrupt and authoritarian regime effectively ignored most of its agreed-upon commitments until the severe deterioration of macro conditions led to a fully fledged collapse and the free fall of the rupiah. The currency board 'saga' following the second IMF plan and the continued resistance of the Indonesian governments to macro and structural reforms were important elements of the financial demise experienced by Indonesia. For the case of Korea, there were serious doubts about the implementation of the first IMF plan, given the coming elections in December and the broad policy uncertainty associated with that event. In Thailand, it was only with a new government truly committed to economic reforms that the value of the baht stabilized, and even appreciated relative to the lows reached in December.

\section{The role of the financial system}

The previous section has highlighted a number of country-specific and global factors that determined the current account imbalances observed in Asia on the eve of the crisis, and undermined their sustainability. In this section, we argue that the key to a comprehensive interpretation of the events leading to the Asian meltdown of 1997 is the analysis of the structure of incentives under which not only the corporate but also the banking and financial sectors operated in the region.

The links between balance of payments crises and banking crises in emerging economies represent a recurrent theme in the policy literature, and they have been (re)emphasized in a number of recent studies. ${ }^{45}$ For instance, the origins of the 1994 Mexican crisis and its impact on other countries in the region have been traced to, inter alia, an excessive build-up of bank credit and a lending 'boom' that represented the outcome of financial market liberalization. ${ }^{46}$ Jeffrey Sachs has presented an early analysis of the role of excessive lending driven by 'moral hazard' incentives:

"Throughout Latin America, Central Europe and South-East Asia, banks have been deregulated and privatized in recent years, allowing them much greater latitude to borrow from abroad. Banks and near-banks — such as Thailand's now notorious financial trusts

\footnotetext{
${ }^{45}$ See e.g. Kaminsky and Reinhart (1997), Goldfajn and Valdes (1997).

${ }^{46}$ See in particular Sachs, Tornell and Velasco (1996).
} 
- become intermediaries for channeling foreign capital into the domestic economy. The trouble is that the newly liberalized banks and near-banks often operate under highly distorted incentives. Under-capitalized banks have incentives to borrow abroad and invest domestically with reckless abandon. If the lending works out, the bankers make money. If the lending fails, the depositors and creditors stand to lose money, but the bank's owners bear little risk themselves because they have little capital tied up in the bank. Even the depositors and the foreign creditors may be secure from risk, if the government bails them out in the case of bank failure. $" 47$

In the overview that follows, we provide evidence on the degree and extent of 'overlending' in Asia, and comment upon its consequences and implications for the unraveling of the 1997-98 crises.

\subsection{The evidence on financial 'overlending': quantity...}

Evidence on the lending boom in the 1990s is provided by the data on the growth of bank credit to the private sector (Table 18) and the ratio of private sector lending to GDP (Table 19). Also, as in Sachs, Tornell and Velasco (1996), in Table 20 we provide a synthetic measure of the lending boom by calculating the rate of growth of bank lending as a percentage of GDP ratio in the 1990s. The IMF distinguishes between 'deposit money banks', 'other banking institutions' and 'other financial intermediaries', but information about the latter two categories is missing for many countries. We therefore focus our analysis on 'deposit money banks' and refer to other intermediaries when data are available. ${ }^{48}$

The ratio of private sector lending to GDP shows an upward trend in all the countries in our sample. Between 1990 and 1996, the magnitude of the

\footnotetext{
${ }^{47}$ Financial Times, July 301997 . Along the same lines, a celebrated early analysis of the emergence of a financial crisis in an emerging economy is provided by Diaz-Alejandro (1985). Corsetti, Pesenti and Roubini (1998) formalize these insights in the context of the analysis of the Asian collapse.

${ }^{48}$ For a general assessment of the moral hazard argument in Asia, one should consider that financial deregulation led to the emergence of new non-bank financial intermediaries (such as the finance companies in Thailand), and that these companies often played a key part in the lending boom. Unfortunately, detailed data on lending by all financial intermediaries are not available.
} 
lending boom was largest in the Philippines (151\%), Thailand (58\%) and Malaysia (31\%). It is also large but more modest in Korea, Singapore, Hong Kong and Indonesia. And the measure was the smallest in China (7\%). For a comparison with Mexico and the 'Tequila effect' countries, between 1990 and 1994 the lending boom in Mexico, Argentina and Brazil was 116\%, 57\% and $68 \%$ respectively. ${ }^{49}$

How do our results on the lending boom change when we consider available data on lending by 'other banking institutions' and 'non-bank financial institutions'? In the case of Korea, the measure of lending growth is not altered significantly. For Malaysia, data on 'other banking institutions' are available only for the 1992-95 period, while data on 'non-bank financial institutions' are available only for the 1990-94 period. The growth rate of credit from such institutions appears to be similar to that of commercial banks. In the Philippines lending by 'other banking institutions' was more modest than lending by commercial banks, but overall lending by such institutions was a small fraction (about 10\%) of bank lending.

In Singapore, the credit growth of 'other banking institutions' and nonbanks was very close to that of commercial banks, so that the overall lending boom pattern is confirmed by this extension of the analysis. In Thailand, the lending boom was significantly larger for finance and securities companies than for banks (133\% as opposed to 51\%); moreover, the non-bank share of lending to the private sector was quite significant (about $33 \%$ of bank lending). So, Thailand is the only country in the sample where lending to the private sector is very different if we add the 'other banking' and 'nonbank financial institutions' figures. Data for 'other banking' and 'non-bank financial institutions' are not available for Hong Kong, China and Taiwan. In summary, the evidence suggests a sustained lending boom in the Philippines, Thailand and Malaysia. Note that these were also the first countries to be hit by currency speculation in $199 \%$.

\footnotetext{
${ }^{49}$ These figures on Latin America are from Sachs, Tornell and Velasco (1996). Note that they use a slightly different definition of lending boom, as they consider total lending to the private sector by both banks and the central bank. The difference between the two definition is is not significant, as in most countries central bank credit to the private sector is very modest.
} 


\section{$4.2 \quad$...and quality}

The growth rate of the lending to GDP ratio gives an indication of the quantity of loans. But one of the main problems faced by the countries in our sample is that many loans made by banks and non-banks were of low quality, financing investment of dubious profitability or speculative purchases of existing financial assets. In the investment section above, we have already shown evidence suggesting overinvestment in risky and poorly performing projects. We can now add to the picture evidence on the quality of precrisis lending, by looking at the proportion of non-performing loans to total loans. Since the 1997 crisis may have crippled otherwise healthy loans, it is appropriate to refer exclusively to data on non-performing loans at the onset of the crisis.

As reported in Table 21, the pre-crisis share of non-performing loans as a proportion of total lending can be estimated at 13\% for Thailand, $13 \%$ for Indonesia, $8 \%$ for Korea, 10\% for Malaysia, 14\% for the Philippines and $4 \%$ for Singapore. The estimated share is $3-4 \%$ for Hong Kong and Taiwan, and $14 \%$ for China. ${ }^{50}$ Although the reliability of these estimates varies across countries, the figures show a strong correlation between the amount of bad loans and the extent of the currency crises.

We stress the impact of the real estate sector crisis on the financial position of the banking sector. Table 22 presents end-1997 estimates of property exposure, collateral valuation, non-performing loans and capital of local banks, all as a share of total assets. Property exposure is estimated to be very high in Hong Kong, Malaysia, Singapore and Thailand, while it is relatively low in the Philippines and Korea (where the bad loans were concentrated in manufacturing firms). By the end of 1997, non performing loans of local banks were the highest in Indonesia (11\%), South Korea (16\%) and Thailand (15\%). As the table shows, they are expected to increase sharply in 1998 in all Asian countries, and become especially problematic in Indonesia, South Korea, Thailand and Malaysia. In these four countries, banks were also severely under-capitalized, with capital to asset ratios as low as $6-8 \%$. Note that, at the end of 1997 , this ratio was already below the share of non-performing loans, a share that is expected to worsen in the current year.

The table clarifies the links between high shares of bad loans, an excessive exposure to the property sector, and overly-optimistic estimates of the loans'

\footnotetext{
${ }^{50}$ See Corsetti, Pesenti and Roubini (1998) for details.
} 
collateral. In the four countries with the most severe problems, the official collateral valuations were in the range of 80 to $100 \%$ of assets. ${ }^{51}$ Asset deflation and the sharp drop in the value of the collateral, especially real estate, triggered the irreversible surge in the shares of non-performing loans.

\subsection{Banking problems, financial deregulation, and in- stitutional deficiencies}

In the Asian region, with bond and equity markets relatively underdeveloped, most financial intermediation occurred through the banking system. This meant that the capital inflows financing the region's large current account deficits were largely intermediated by local banks. Specifically, domestic banks borrowed from foreign banks and then, in turn, lent on to domestic firms, so that when domestic firms experienced financial difficulties, domestic banks were faced with non-performing domestic assets and short-term foreign-currency liabilities.

Such 'overborrowing' and 'overlending' syndromes within the undercapitalized banking systems were the outcome of severe institutional and policy deficiencies. There is indeed overwhelming evidence that the Asian banking and financial systems were very fragile - poorly supervised, poorly regulated, and in a shaky condition even before the onset of the crisis. In Thailand, regulation of commercial banks limited their credit expansion, but financial liberalization in the 1990s led to the emergence of other largely unregulated non-bank intermediaries that could circumvent credit limits. Moreover, Thai policies provided strong tax-incentives to offshore borrowing. In the 1990s, Thai finance companies sharply accelerated their lending to the real estate and property sector, mainly financed with borrowing from foreign financial institutions.

In Korea the financial system was in a severe crisis because of excessive lending to large traded-sector conglomerates, a number of which went bankrupt before the currency crisis hit in late 1997. It should be noted that, in several cases, private banks in Korea were effectively controlled by chaebols, giving those conglomerates privileged access to credit and exacerbating the moral hazard problem.

In Indonesia, although official prudential requirements for domestic banks were in line with Basle Committee recommendations, compliance and en-

\footnotetext{
${ }^{51}$ The source is JP Morgan.
} 
forcement were low. According to central bank statistics, from a total of 240 banks in April 1996, 15 did not meet the required 8\% capital adequacy ratio, 41 did not comply with the legal spending limit, and 12 out of 77 licensed foreign exchange banks did not meet the rules on net overnight positions.

While in the 1980s the banking system had been dominated by five large state-owned banks, accounting for $80-90 \%$ of all bank credit, in the $1990 \mathrm{~s}$ following a wide-ranging series of reforms in 1988/89 — the private banking sector grew rapidly, surpassing the state sector by 1994. Overall, banks accounted for almost two-thirds of total corporate finance, while stock markets provided one third. Rapid growth within this deregulated system, along with the struggle for market shares, resulted in a system containing an excessive number of small undercapitalized banks (a problem pointed out by IMF economists in November 1996, and also highlighted by Standard \& Poors in January 1996), which was vulnerable to poorly chosen or fraudulent lending. 52

Rather than shutting down ailing banks - only one, Bank Summa in 1992, had ever been liquidated — the Indonesian government's preferred course of action was to encourage mergers, or other forms of support. ${ }^{53}$ With such government support in prospect, the incentives of small undercapitalized banks were clearly biased toward riskier projects. The asset quality of state banks was even worse than that of private banks, due to their even greater confidence in government support (the Finance Ministry announced in 1994 that it would not permit a state bank to default on its obligations), or to their greater susceptibility to government direction in their lending patterns. As of end-1995, state banks had an average non-performing debt level of $17 \%$, compared to $5 \%$ for the private sector as a whole.

Until 1995, Malaysia's banking problems were not as serious as Indone-

\footnotetext{
${ }^{52}$ The most spectacular case of poor lending emerged with the rescue of Bank Bapindo, a government development bank, which had built up a overwhelming portfolio of nonperforming loans, and had lent USD 420 million to an obscure businessman who absconded after being jailed with other Bapindo officials for corruption. Similarly, Lippo Bank faced a bank run in November 1995, following reports that it had not disclosed its exposure to sister companies in the Lippo group - companies that had been involved in highly speculative real estate ventures. The bank was rescued by a group of private banks which agreed to provide short-term liquidity.

${ }^{53}$ In April 1996, Bank Negara Indonesia was told to 'nurse' two ailing banks closely affiliated with Suharto's family - Bank Yama, owned by President Suharto's eldest daughter, and Bank Pacific, run by the daughter of the founder of the state-run oil monopoly Pertamina.
} 
sia's, but there is evidence of excessive lending in highly risky projects, which escalated in 1996 and early 1997. Recognizing that Malaysia had too many small banks to be internationally competitive, Bank Negara had been steadily urging consolidation of the banking sector. In 1996 the proportion of nonperforming loans to total credits dropped to $3.9 \%$ from $5.5 \%$ in 1995 , due to recoveries associated both with economic growth and write-offs. But 1996 witnessed an overall increase in bank lending by $27.6 \%$, with a sharp switch from lending to the manufacturing sector to lending for equity purchases: growth in lending to the manufacturing sector fell to $14 \%$ in 1996 (from $30.7 \%$ in 1995), while growth in lending for share purchases accelerated to $20.1 \%$ (from $4 \%$ in 1995).

By the end of 1996, the banking system's exposure to the property sector and equities stood at $42.6 \%$ of total credits, compared to $21 \%$ for manufacturing finance. Over the year, the increased availability of loans drove up asset prices, with the price of up-market properties in major Malaysian cities growing by $25 \%$ in 1996 . Property and equity financing continued to rise rapidly in early 1997 . The Malaysian central bank eventually intervened to slow the growth of lending for real estate speculation and equity purchases, but these actions were too little, too late. Only on March 1997 did Bank Negara announce ceilings on lending to the property sector and for purchases of stocks and shares.

\section{Imbalances in foreign debt accumulation and management}

\subsection{The foreign debt burden and the role of short-term external debt}

An otherwise solvent country may suffer a short-run liquidity problem when the available stock of reserves is low relative to the overall burden of external debt service (interest payments plus the renewal of loans coming to maturity). Liquidity problems emerge when panicking external creditors - perhaps in response to rapid devaluation - become unwilling to roll over existing shortterm credits. So, if a large fraction of a country's external liabilities are shortterm, a crisis may take the form of a pure liquidity shortfall - the inability by a country to roll-over its short-term liabilities. The experience of Mexico 
with its short-term public debt (Tesobonos) in 1994-95, and of several Asian countries with private external liabilities in 1997 provides striking examples of liquidity problems. ${ }^{54}$

Comparable estimates of the debt-service burden and the external liabilities of the Asian countries are available from three sources. The first is the World Bank, which provides annual estimates of the external debt of developing countries. ${ }^{55}$ The second source consists of two series of data published by the BIS. One BIS series ${ }^{56}$ is published quarterly and presents data on the liabilities and assets of domestic agents (both domestic banks and nonbanking institutions, i.e. private firms and other large public sector agents) towards the BIS reporting banks. The other BIS series ${ }^{57}$ is published every six months and contains consolidated data on liabilities toward BIS banks, including their maturity - allowing for a precise measure of short-term lending from BIS reporting banks to a particular developing country. Finally, the OECD also collects yearly data on the external liabilities of developing countries. $^{58}$

If we use the estimates developed by the World Bank, it is hard to notice any serious problems for the countries hit by the crisis. As can be seen from Table 23, the debt-to-GDP ratio for many of these countries was relatively low and growing only modestly, or else high but actually falling during the 1990s. In Korea, the ratio was around $14 \%$ between 1990 and 1995 . It was relatively high in Indonesia in 1991 (68\%), falling to $57 \%$ by 1996; in Malaysia, it gravitated around $40 \%$ since 1993. In the Philippines, the

\footnotetext{
${ }^{54}$ At a theoretical level, a number of recent analyses emphasize that a relatively large share of short-term debt makes the occurrence of self-fulfilling debt crises more likely (see Cole and Kehoe (1996) and Sachs, Tornell and Velasco (1996)).

${ }^{55}$ The World Bank data on long-term debt are quite precise but its estimates of shortterm debt, especially the external liabilities of the banking system, are less reliable. Moreover, the World Bank measure of the debt-servicing ratio has serious shortcomings as it includes interest payments on all foreign debt but principal payments only for long-term debt — so the roll-over of short term liabilities that was an essential issue in the 1997 Asian crisis is not considered. Also, the annual World Bank data are published with considerable delay (usually one year and often two years).

${ }^{56}$ These are the data in the BIS publication International banking and financial market developments.

${ }^{57}$ This is the BIS publication The maturity, sectoral and nationality distribution of international bank lending.

${ }^{58}$ The OECD estimates of long-term debt are comparable to those of the World Bank; however, the OECD estimates of short-term liabilities are closer to those provided by the BIS.
} 
ratio fell from a high $69 \%$ of GDP in 1991 to $53 \%$ in 1995. In Thailand, it barely moved from 33\% of GDP in 1990 until 1996, while in Singapore and Taiwan external debt was practically non-existent. ${ }^{59}$ The ratio for China grew from $14 \%$ in 1990 to $18 \%$ in 1994 but still remained relatively low.

World Bank figures also suggest that the share of short-term debt was relatively modest, albeit growing (see Table 24): about $25 \%$ in Korea in 1994; $25 \%$ in Indonesia in 1996, up from $16 \%$ in 1990; $28 \%$ in Malaysia in 1996, up from $12 \%$ in $1990 ; 19 \%$ in the Philippines in $1996 ; 41 \%$ in Thailand in 1996 (although it was over 70\% in 1995) and 20\% in China in 1996. As for the debt service ratio, the World Bank estimates for the Asian countries in our sample are also quite low, as they do not include the rollover of short-term liabilities. The debt service ratio is defined as the interest on all debt plus the principal to be repaid on long-term debt as a share of total exports. During the 1990s, this debt-service ratio was well below $10 \%$ in many countries of the region (see Table 25). Exceptions were Indonesia, with a ratio above $30 \%$; the Philippines, with a ratio which started above $20 \%$ but fell to $16 \%$ by 1995 ; and Thailand, with a ratio as high as $13 \%$ until 1994, but down to $11.6 \%$ by 1995 .

The picture looks somewhat more troubling if we consider the ratio of short-term debt to foreign reserves, and the ratio of debt-service plus shortterm debt to foreign reserves. If a liquidity crisis occurs, foreign reserves must be large enough to cover a country's debt service obligations (including the roll-over of short-term debt). The figures corresponding to the two ratios described above are presented in Tables 26 and 27. By the latest available data (1996 for all countries except Korea, for which data refer to 1994), these ratios were: $54 \%$ and $85 \%$ for Korea; $177 \%$ and $294 \%$ in Indonesia; $41 \%$ and $69 \%$ in Malaysia; $79 \%$ and $137 \%$ in the Philippines; $100 \%$ and $123 \%$ in Thailand; $24 \%$ and $38 \%$ in China.

We look next at quarterly BIS data on the external assets and liabilities of domestic banks and non-banks towards BIS reporting banks. Table 28 presents the data on a country-by-country basis, while Table 29 reports the

\footnotetext{
${ }^{59}$ Data on Singapore, Hong Kong and Taiwan are from the Asian Development Bank, since these countries are not considered as developing by the World Bank, and therefore are not included in the debt tables provided by this institution. Since 1996, the World Bank also stopped reporting data on Korea, after this country was promoted to the status of developed OECD country. In tables 23-27, the source for Korean data in 1995 and 1996 (in italics) is the OECD; the lack of homogeneity between the World Bank and the OECD estimates is transparent.
} 
ratio of total liabilities to GDP for all countries in the sample. First, by comparing Tables 23 and 29, we note that for Korea and Thailand foreign liabilities of domestic agents towards BIS banks are larger than the World Bank estimates of total foreign debt. This observation suggests that the World Bank estimates, especially those of domestic agents' liabilities towards foreign banks, may be seriously biased downward.

The second point to note is that, in most countries, foreign liabilities towards BIS reporting banks are liabilities of domestic banks, as opposed to liabilities of the corporate or public non-bank sector. For example, by the second quarter of 1997, about $77 \%$ of all Korean liabilities towards BIS banks concerned domestic banks. This confirms our previous observation that a large fraction of Asian borrowing from foreign banks was intermediated by the domestic banking system. In mid-1997 the ratio of intermediation handled by domestic banks was $77 \%$ for Malaysia, $69 \%$ for the Philippines, $86 \%$ for Thailand, and $78 \%$ for China. The only country with significant external borrowing by non-banks was Indonesia, where the ratio for banks was $39 \%$.

It is worth pointing out that the banking share of total liabilities is quite different if we use the second set of data published by the BIS, as presented in Table 30. According to the latter figures, in mid-1997 the banks' liabilities represented $44 \%$ of the total in Korea, $38 \%$ in Thailand, $21 \%$ in Indonesia, $36 \%$ in Malaysia, $62 \%$ in Taiwan and $43 \%$ in China. ${ }^{60}$ Hong Kong and Singapore exhibit a very large ratio of foreign liabilities to GDP as well as a large ratio of foreign assets to GDP; their net external liabilities towards BIS banks appear to be quite large but these two countries are very important international financial centers, so external liabilities toward BIS banks need not be representative of their overall liabilities.

For the other countries in the sample, foreign liabilities tend to be very large, even after netting out foreign assets. For example, in the case of Korea

\footnotetext{
${ }^{60}$ The two series differ in a number of aspects: the quarterly series include liabilities towards BIS banks in Singapore, Hong Kong and other offshore centers, something missing in the other series. The quarterly series distinguishes only between non banks and, residually, bank liabilities towards BIS banks; while the other presents data for non-bank private sector, public sector and bank liabilities. The quarterly data present data both on assets and liabilities towards BIS banks. The other series has the benefit of presenting consolidated cross-border claims in all currencies and local claims in non-local currencies. These differences lead to quite different figures for total liabilities and very different data for the banking and private sector share of such liabilities. For the sake of completeness we present both series even if we focus on the quarterly data.
} 
external liabilities increased from USD 45 billion in 1993 to USD 116 billion in 1997: after subtracting foreign assets, we still observe a net debt as high as USD 30 billion in 1993, reaching USD 80 billion in 1997. As discussed above, most of these net liabilities are by Korean banks (about USD 57 billion by mid-1997), but the liabilities of non-banks are sizeable as well (about USD 23 billion). For other Asian countries, both gross and net liabilities are large and growing rapidly in the 1990s. In Indonesia, gross liabilities grow from USD 37 billion in 1993 to USD 60 billion in 1997, while net liabilities are as high as USD 49 billion in 1997. Similar trends are observed in Malaysia, the Philippines and Thailand. In the latter country gross (net) liabilities grow from USD 34 billion (29 billion) in 1993 to 98 billion (90 billion) in 1997.

Table 31 reports the ratio of foreign liabilities to assets relative to BIS reporting banks. This ratio is above unity for all crisis countries, and deteriorates severely in the 1990s. In an extreme case, Thailand, it reaches 1,103\% in 1996. In Korea, it is $297 \%$ in 1993, and reaches $375 \%$ in 1996 - the same patterns emerge if we focus on foreign liabilities and assets of domestic banks only. In 1996, equally worrisome ratios are observed in Indonesia (424\%), the Philippines (172\%), Hong Kong (165\%), Singapore (162\%) and Malaysia (148\%). Conversely, the ratio is lower in China (120\%). The case of Taiwan is interesting as it is the only country in our sample that has a net positive assets position (the ratio is lower than unity). Net assets are equal to USD 12.2 billion in 1997, 7.5 billion for the Taiwan banking system alone.

The above figures suggest a serious mismatch between foreign liabilities and foreign assets of Asian banks and non-bank firms. Domestic banks borrowed heavily from foreign banks but lent mostly to domestic investors. In normal times a high ratio of foreign liabilities to foreign assets may not cause concern, as short-term foreign debts are easily rolled-ever. In the presence of a rapid currency depreciation, however, this imbalance may cause serious financial problems (especially if the foreign borrowing is in foreign currency while the domestic lending is in domestic currency). Foreign lenders may suddenly refuse to roll over short-term lines of credit to domestic banks, precipitating a credit crisis. To a large extent, this is what happened in 1997.

The BIS figures on foreign liabilities appear particularly problematic when we consider their maturity structure. This piece of information is presented in Table 32. By the end of 1996, a share of short-term foreign liabilities above $50 \%$ was the norm in the region. The percentage of loans with a 
maturity of up to one year was $67 \%$ in Korea, $65 \%$ in Thailand, $61 \%$ in Indonesia, 50\% in Malaysia, 58\% in the Philippines, $49 \%$ in China, $84 \%$ in Taiwan, $82 \%$ in Hong Kong and $92 \%$ in Singapore. Of the latter three countries, however, Taiwan was a net creditor, while the data for Hong Kong and Singapore reflect the role of these countries as large financial and intermediation centers.

\subsection{Foreign exchange reserves}

The existence of large foreign exchange reserves facilitates the financing of a current account deficit, and enhances the credibility of a fixed exchange rate policy. Foreign exchange reserves and a small external debt burden reduce the risk of external crises, and enable a country to finance a current account deficit at lower costs. The real rate paid (in hard currency terms) on the country's debt is an indication of the market's evaluation of the country's ability to sustain a current account deficit.

A traditional measure of the adequacy of foreign exchange reserves is the stock of reserves in months of imports (of goods and services) - this measure is reported in Table 33. As rapid outflows of speculative money have become a more important source of foreign exchange pressure than trade imbalances, the above indicator is no longer regarded as a good measure of reserve adequacy. A better indicator of adequacy is the ratio of money assets to foreign reserves, since in the event of an exchange rate crisis or panic, all liquid money assets can potentially be converted into foreign exchange. Calvo (1998) suggests the ratio of a broad measure of liquid monetary assets to foreign reserves, for instance — as in Sachs, Tornell and Velasco (1996) - the ratio of M2 to foreign reserves. ${ }^{61}$

Tables 34 and 35 report both the ratio of M1 to foreign reserves (M1/FX) and the ratio of M2 to foreign reserves (M2/FX). For the purpose of comparison, it is worth recalling that, just before the Mexican peso crisis (November 1994), M2/FX was equal to 9.1 in Mexico, and equal to 3.6 in both Brazil and Argentina - the two countries that were most affected by the 'tequila effect'.

\footnotetext{
${ }^{61} \mathrm{~A}$ problem in interpreting the evidence is that the ratio of M2 to GDP varies a great deal across countries, depending on the development of the banking system and the level of financial intermediation. The M2 to reserves ratio may be high because banking intermediaries are relatively more developed.
} 
In most Asian countries the ratio between $M 2$ and foreign reserves was dangerously high in 1996-97. In Korea, this ratio was equal to 6.5 by the end of 1996, and rose to almost 7 in the first quarter of 1997. In Indonesia M2/FX constantly rose throughout the 1990s and reached a peak as high as 7.09 in 1995. In Malaysia, the ratio was a bit lower, but increasing from 2.9 in 1990 to 3.7 at the end of 1996. In the Philippines the ratio declined marginally from 4.8 in 1991 to 4.5 in 1996. In Thailand the ratio went from 4.5 in 1990 to 3.9 in 1996. In Singapore, the ratio was as low as 1.2 in 1990, and fell further to 1.03 in 1996. And finally, in 1996, the ratio was at 4.2 in Hong Kong, and at 8.5 in China.

The figure for the M1 to reserves ratio are smaller, reflecting the importance of 'Quasi Money', included in M2 but not in M1. At the end of 1996, the M1 to reserve ratio was above unity in China (3.45), Korea (1.44), Indonesia (1.21), and Malaysia (1.16) It was below unity in Singapore (0.25), Hong Kong (0.35), Thailand (0.44), and the Philippines (0.89). Note that while China had the highest ratios, the ability of Chinese residents to convert domestic liquid assets into foreign currency is severely limited by widespread capital controls that are absent in most of the other countries in the region.

To provide another indicator of financial fragility, Table 36 reports the ratio of total short-term external liabilities (towards BIS banks) to foreign reserves at the end of 1996 . This ratio was $213 \%$ in Korea, $181 \%$ in Indonesia, $169 \%$ in Thailand, $77 \%$ in the Philippines, $47 \%$ in Malaysia and $36 \%$ in China. These figures mean that, by the end of 1996, in the event of a liquidity crisis with BIS banks no longer willing to roll-over short-term loans, foreign reserves in Korea, Indonesia and Thailand were insufficient to cover short term liabilities, let alone to service interest payments and to repay the principal on long-term debt coming to maturity in the period. When we add interest and long-term principal repayment, the Philippines and Malaysia would have also found it impossible to meet their external obligations. ${ }^{62}$

\subsection{Composition and size of the capital inflows}

As noted above, current account sustainability is enhanced when the deficit is largely financed by foreign direct investment (FDI), relative to a deficit mainly financed by short-term flows that may be reversed if market condi-

\footnotetext{
${ }^{62}$ The OECD data confirm the above analysis of the growth of short-term debt.
} 
tions and sentiments change. Inflows from official creditors are more stable and less subject to sharp reversals in the short-run than those from private creditors; loans from foreign banks are less volatile than portfolio inflows (bonds and non-FDI equity investments). External sustainability also depends on the currency composition of a country's foreign liabilities. Borrowing in foreign currency is generally associated with greater capital inflows at a lower interest rate than issuing debt denominated in domestic currency (since risk averse investors concerned about inflation and exchange rate risk prefer foreign-currency denominated assets). However debt denominated in foreign currency may end up exacerbating an exchange rate crisis, as the depreciation of the local currency increases the real burden of foreign debt. ${ }^{63}$

Table 37 shows the extent to which Asia's current account imbalances were financed with non-debt creating long-term FDI flows. There is a wide range of experiences. Some countries such as Korea and Thailand financed only a small and falling fraction of their current account deficits with longterm FDI. By 1996, this fraction was 10\% for Korea and 16\% for Thailand. Other countries relied much more on FDI - in Indonesia, FDI inflows were 60-90\% of the current account deficit between 1992 and 1995, whereas in Malaysia the ratio was well above $100 \%$ in 1992-1993, but then fell to about $90 \%$ in 1994-1995. In the Philippines, the ratio was quite volatile in the 1990s, but on average FDI covered $45 \%$ of the current account deficit. ${ }^{64}$

Another important point to consider is that net capital inflows different from FDI (portfolio assets, bonds, portfolio equity, bank borrowings) were often large enough, relative to the current account deficit and net FDI flows, so that the overall balance of payments was in surplus - producing a net accumulation of foreign exchange reserves. ${ }^{65}$ The evidence on international

\footnotetext{
${ }^{63}$ In the experience of Mexico in 1995, the depreciation of the peso in the presence of a large amount of short-term dollar denominated Tesobonos generated a liquidity crisis that almost turn into a default crisis.

${ }^{64}$ In countries such as Korea and Thailand, there were also considerable FDI outflows, so that the net contribution of FDI to the financing of the current account was smaller than suggested by the gross figures. Specifically, Korean FDI outflows were greater than inward FDI in each year of the 1990s. By 1996 FDI outflows were USD 4.4 billion, while FDI inflows were only USD 2.3 billion. In Thailand, net FDI flows were positive but by 1996 FDI outflows were as high as USD 1 billion, against inflows for USD 2.3 billion. So, in 1996, the net contribution of FDI to the financing of Thailand's current account was $9 \%$, much smaller than the gross contribution of $16 \%$ as reported above.

${ }^{65}$ As a reminder, Current Account + Net FDI + Other Net Capital Inflows $=$ Change in Foreign Reserves.
} 
reserves is shown in Table 38. For all countries in the region, the growth of foreign reserves between 1990 and 1996 was quite remarkable - 127\% in Korea, $144 \%$ in Indonesia, $176 \%$ in Malaysia, $985 \%$ in the Philippines, $176 \%$ in Singapore, $183 \%$ in Thailand, $159 \%$ in Hong Kong, and $261 \%$ in China. To the extent that these interventions were sterilized, domestic interest rates remained high and capital inflows did not fall, maintaining the upward pressure on the exchange rate. ${ }^{66}$

${ }^{66}$ The second part of the paper includes sections 6-10, table 39, and references. 
Table 1. Current Account, NIA Definition (\% of GDP)

$\begin{array}{lrrrrrrrr} & \mathbf{1 9 9 0} & \mathbf{1 9 9 1} & \mathbf{1 9 9 2} & \mathbf{1 9 9 3} & \mathbf{1 9 9 4} & \mathbf{1 9 9 5} & \mathbf{1 9 9 6} & \mathbf{1 9 9 7} \\ \text { Korea } & -1.24 & -3.16 & -1.70 & -0.16 & -1.45 & -1.91 & -4.82 & -1.90 \\ \text { Indonesia } & -4.40 & -4.40 & -2.46 & -0.82 & -1.54 & -4.27 & -3.30 & -3.62 \\ \text { Malaysia } & -2.27 & -14.01 & -3.39 & -10.11 & -6.60 & -8.85 & -3.73 & -3.50 \\ \text { Philippines } & -6.30 & -2.46 & -3.17 & -6.69 & -3.74 & -5.06 & -4.67 & -6.07 \\ \text { Singapore } & 9.45 & 12.36 & 12.38 & -8.48 & 18.12 & 17.93 & 16.26 & 13.90 \\ \text { Thailand } & -8.74 & -8.01 & -6.23 & -5.68 & -6.38 & -8.35 & -8.51 & -2.35 \\ \text { Hong Kong } & 8.40 & 6.58 & 5.26 & 8.14 & 1.98 & -2.97 & -2.43 & -3.75 \\ \text { China } & 3.02 & 3.07 & 1.09 & -2.19 & 1.16 & 0.03 & 0.52 & 3.61 \\ \text { Taiwan } & 7.42 & 6.97 & 4.03 & 3.52 & 3.12 & 3.05 & 4.67 & 3.23\end{array}$

Note: The source of all data in these Tables is the International Financial Statistics of the International

Monetary Fund (unless otherwise noted). The data for Taiwan are from various sources (Economist Intelligence

Unit Reports, IMF's December 1997 World Economic Outlook and Asian Development Bank). The data for

Singapore for 1997 are from the Economist Intelligence Unit Country Report, 2nd quarter 1998.

Table 2. Current Account, BOP Definition (\% of GDP)

$\begin{array}{lrrrrrrrr} & \mathbf{1 9 9 0} & \mathbf{1 9 9 1} & \mathbf{1 9 9 2} & \mathbf{1 9 9 3} & \mathbf{1 9 9 4} & \mathbf{1 9 9 5} & \mathbf{1 9 9 6} & \mathbf{1 9 9 7} \\ \text { Korea } & -0.69 & -2.83 & -1.28 & 0.30 & -1.02 & -1.86 & -4.75 & -1.85 \\ \text { Indonesia } & -2.82 & -3.65 & -2.17 & -1.33 & -1.58 & -3.18 & -3.37 & -2.24 \\ \text { Malaysia } & -2.03 & -8.69 & -3.74 & -4.66 & -6.24 & -8.43 & -4.89 & -4.85 \\ \text { Philippines } & -6.08 & -2.28 & -1.89 & -5.55 & -4.60 & -2.67 & -4.77 & -5.23 \\ \text { Singapore } & 8.33 & 11.29 & 11.38 & 7.57 & 16.12 & 16.81 & 15.65 & 15.37 \\ \text { Thailand } & -8.50 & -7.71 & -5.66 & -5.08 & -5.60 & -8.06 & -8.10 & -1.90 \\ \text { China } & 3.09 & 3.27 & 1.33 & -1.94 & 1.26 & 0.23 & 0.87 & 3.24 \\ \text { Taiwan } & 6.82 & 6.94 & 4.03 & 3.16 & 2.70 & 2.10 & 4.05 & 2.72\end{array}$

Table 3: Trade Balance, BOP Definition (\% of GDP)

$\begin{array}{lrrrrrrrr} & \mathbf{1 9 9 0} & \mathbf{1 9 9 1} & \mathbf{1 9 9 2} & \mathbf{1 9 9 3} & \mathbf{1 9 9 4} & \mathbf{1 9 9 5} & \mathbf{1 9 9 6} & \mathbf{1 9 9 7} \\ \text { Korea } & -0.81 & -3.04 & -1.42 & 0.06 & -1.22 & -1.63 & -4.36 & -1.44 \\ \text { Indonesia } & 1.68 & 0.91 & 1.81 & 1.48 & 0.72 & -0.76 & -1.14 & 0.22 \\ \text { Malaysia } & 2.10 & -3.74 & 1.39 & -0.11 & -1.59 & -3.75 & 0.58 & \\ \text { Philippines } & -5.73 & -3.00 & -4.27 & -8.53 & -8.95 & -8.80 & -9.44 & -12.30 \\ \text { Singapore } & 6.76 & 10.62 & 9.29 & 8.12 & 14.87 & 15.38 & 13.62 & 12.55 \\ \text { Thailand } & -7.75 & -6.88 & -4.70 & -4.56 & -5.18 & -7.09 & -6.65 & 0.14 \\ \text { China } & 2.75 & 2.86 & 1.03 & -1.92 & 1.39 & 1.68 & 2.10 & 4.41 \\ \text { Taiwan } & 4.74 & 4.39 & 1.69 & 1.60 & 1.66 & 1.61 & 3.45 & 2.35\end{array}$

Table 4. GDP Growth

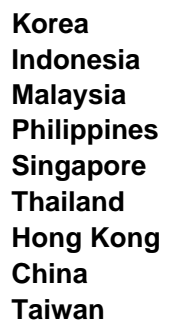

Taiwan

$\begin{array}{rrrrrrr}1991 & 1992 & \mathbf{1 9 9 3} & \mathbf{1 9 9 4} & \mathbf{1 9 9 5} & \mathbf{1 9 9 6} & \mathbf{1 9 9 7} \\ & & & & & & \\ 9.13 & 5.06 & 5.75 & 8.58 & 8.94 & 7.10 & 5.47 \\ 6.95 & 6.46 & 6.50 & 15.93 & 8.22 & 7.98 & 4.65 \\ 8.48 & 7.80 & 8.35 & 9.24 & 9.46 & 8.58 & 7.81 \\ -0.58 & 0.34 & 2.12 & 4.38 & 4.77 & 5.76 & 9.66 \\ 7.27 & 6.29 & 10.44 & 10.05 & 8.75 & 7.32 & 7.55 \\ 8.18 & 8.08 & 8.38 & 8.94 & 8.84 & 5.52 & -0.43 \\ 4.97 & 6.21 & 6.15 & 5.51 & 3.85 & 5.03 & 5.29 \\ 9.19 & 14.24 & 12.09 & 12.66 & 10.55 & 9.54 & 8.80 \\ 7.55 & 6.76 & 6.32 & 6.54 & 6.03 & 5.67 & 6.81\end{array}$


Table 5. Investment Rates (\% of GDP)

$\begin{array}{lcccccccc} & \mathbf{1 9 9 0} & \mathbf{1 9 9 1} & \mathbf{1 9 9 2} & \mathbf{1 9 9 3} & \mathbf{1 9 9 4} & \mathbf{1 9 9 5} & \mathbf{1 9 9 6} & \mathbf{1 9 9 7} \\ \text { Korea } & & & & & & & & \\ \text { Indonesia } & 36.93 & 38.90 & 36.58 & 35.08 & 36.05 & 37.05 & 38.42 & 34.97 \\ \text { Malaysia } & 36.15 & 35.50 & 35.87 & 29.48 & 31.06 & 31.93 & 30.80 & 31.60 \\ \text { Philippines } & 31.34 & 37.25 & 33.45 & 37.81 & 40.42 & 43.50 & 41.54 & 42.84 \\ \text { Singapore } & 24.16 & 20.22 & 21.34 & 23.98 & 24.06 & 22.22 & 24.02 & 24.84 \\ \text { Thailand } & 35.87 & 34.21 & 35.97 & 37.69 & 32.69 & 33.12 & 35.07 & 37.40 \\ \text { Hong Kong } & 41.08 & 42.84 & 39.97 & 39.94 & 40.27 & 41.61 & 41.73 & 34.99 \\ \text { China } & 27.44 & 27.20 & 28.50 & 27.54 & 31.85 & 34.91 & 32.38 & 35.08 \\ \text { Taiwan } & 34.74 & 34.77 & 36.17 & 43.47 & 40.88 & 40.20 & 38.73 & 37.55 \\ & 23.08 & 23.29 & 24.90 & 25.16 & 23.87 & 23.65 & 21.24 & 22.20\end{array}$

Table 6. Incremental Capital Output Ratio (ICOR)

$1987-92 \quad 1993-96$

$\begin{array}{lll}\text { Korea } & 3.8 & 4.9 \\ \text { Indonesia } & 4.0 & 3.8 \\ \text { Malaysia } & 3.7 & 4.8 \\ \text { Philippines } & 6.0 & 5.5 \\ \text { Singapore } & 3.6 & 4.0\end{array}$

Source: JP Morgan and authors calculations.

Table 7. Financial Conditions of Top 30 Korean Chaebol at the end of 1996 (in hundred million won and \%).

\begin{tabular}{|c|c|c|c|c|c|}
\hline Chaebol & Total Assets & Debt & Sales & Net Profit & Debt/Equity Ratio \\
\hline Samsung & 508.6 & 370.4 & 601.1 & 1.8 & 268.2 \\
\hline Hyundai & 531.8 & 433.2 & 680.1 & 1.8 & 439.1 \\
\hline Daewoo & 342.1 & 263.8 & 382.5 & 3.6 & 337.3 \\
\hline LG & 370.7 & 287.7 & 466.7 & 3.6 & 346.5 \\
\hline Hanjin & 139.0 & 117.9 & 87.0 & -1.9 & 556.9 \\
\hline Kia & 141.6 & 118.9 & 121.0 & -1.3 & 523.6 \\
\hline Ssangyong & 158.1 & 127.0 & 194.5 & -1.0 & 409.0 \\
\hline Sunkyong & 227.3 & 180.4 & 266.1 & 2.9 & 385.0 \\
\hline Hanhwa & 109.7 & 97.2 & 96.9 & -1.8 & 778.2 \\
\hline Daelim & 57.9 & 45.9 & 48.3 & 0.1 & 380.1 \\
\hline Kumho & 74.0 & 61.2 & 44.4 & -0.2 & 477.9 \\
\hline Doosan & 64.0 & 55.9 & 40.5 & -1.1 & 692.3 \\
\hline Halla & 66.3 & 63.2 & 52.9 & 0.2 & 2067.6 \\
\hline Sammi & 25.2 & 25.9 & 14.9 & -2.5 & 3245.0 \\
\hline Hyosung & 41.2 & 32.5 & 54.8 & 0.4 & 373.2 \\
\hline Hanil & 26.3 & 22.3 & 13.0 & -1.2 & 563.2 \\
\hline Donga Construction & 62.9 & 49.1 & 38.9 & 0.4 & 355.0 \\
\hline Kohap & 36.5 & 31.2 & 25.2 & 0.3 & 589.5 \\
\hline Jinro & 39.4 & 39.0 & 14.8 & -1.6 & 8598.7 \\
\hline Dongguk Jaekank & 37.0 & 25.4 & 30.7 & 0.9 & 210.4 \\
\hline Lotte & 77.5 & 51.0 & 71.9 & 0.5 & 191.2 \\
\hline Kolon & 38.0 & 28.9 & 41.3 & 0.2 & 316.5 \\
\hline Haitai & 34.0 & 29.5 & 27.2 & 0.4 & 658.3 \\
\hline Sinho Jaeji & 21.3 & 17.7 & 12.2 & -0.1 & 489.5 \\
\hline Anam Industrial & 26.4 & 21.8 & 19.8 & 0.1 & 478.1 \\
\hline Dongguk Muyok & 16.2 & 13.6 & 10.7 & -0.2 & 587.9 \\
\hline New Core & 28.0 & 25.9 & 18.3 & 0.2 & 1224.0 \\
\hline Bongil & 20.3 & 18.3 & 8.7 & -0.9 & 920.5 \\
\hline Hansol & 47.9 & 37.1 & 25.5 & -0.1 & 343.2 \\
\hline Hansin Kongyong & 13.3 & 11.5 & 10.6 & 0.0 & 648.8 \\
\hline
\end{tabular}

Thailand
Hong Kong
China
Taiwan

$1987-92 \quad 1993-96$

$\begin{array}{ll}3.4 & 5.1 \\ 3.7 & 6.1 \\ 3.1 & 2.9 \\ 2.4 & 3.9\end{array}$


Table 8. Profitability of Korean Chaebols. ROIC in 1992-1996.

$\begin{array}{lrr}\text { Chaebol } & \mathbf{1 9 9 2 - 9 6} & \mathbf{1 9 9 6} \\ \text { Hanbo } & 3.0 \% & 1.7 \% \\ \text { Sammi } & 2.9 \% & 3.2 \% \\ \text { Jinro } & 2.7 \% & 1.9 \% \\ \text { Kia } & 18.9 \% & 8.7 \% \\ \text { Dainong } & 6.8 \% & 5.5 \%\end{array}$

Source: LG Economic Research Institute

Table 9. Central Business District office vacancy rates and rental yields.

\begin{tabular}{lrrl} 
& \multicolumn{2}{c}{ Vacancy Rates } & $\begin{array}{l}\text { Rental yield } \\
\text { Jun-97 }\end{array}$ \\
Seoul & $\mathbf{1 9 9 7}$ & $\mathbf{1 9 9 8 - 9 9}$ & $9.50 \%$ \\
Jakarta & & & $7.20 \%$ \\
Kuala Lumpur & $10.0 \%$ & $20.0 \%$ & $5.80 \%$ \\
Manila & $3.0 \%$ & $20.0 \%$ & $9.30 \%$ \\
Singapore & $1.0 \%$ & $3.0 \%$ & $3.90 \%$ \\
Bangkok & $8.0 \%$ & $12.0 \%$ & $6.80 \%$ \\
Hong Kong & $15.0 \%$ & $20.0 \%$ & $3.50 \%$ \\
Shanghai & $6.0 \%$ & $10.0 \%$ & $8.00 \%$ \\
Taipei & $30.0 \%$ & $40.0 \%$ & $4.80 \%$
\end{tabular}

Source: JP Morgan "Asian Financial Markets", January 1998. 1997 figures for vacancy rates are estimates; 1998-99 figures are forecasts.

Table 10. Stock market prices indexes

\begin{tabular}{|c|c|c|c|c|c|c|c|c|}
\hline & 1990 & 1991 & 1992 & 1993 & 1994 & 1995 & 1996 & 1997 \\
\hline Korea & 696.00 & 610.00 & 678.00 & 866.00 & 1027.00 & 882.00 & 651.00 & 376.00 \\
\hline Indonesia & 417.00 & 247.00 & 274.00 & 588.00 & 469.00 & 513.00 & 637.00 & 401.00 \\
\hline Malaysia & 505.00 & 556.00 & 643.00 & 1275.00 & 971.00 & 995.00 & 1237.00 & 594.00 \\
\hline Philippines & 651.00 & 1151.00 & 1256.00 & 3196.00 & 2785.00 & 2594.00 & 3170.00 & 1869.00 \\
\hline Singapore & 1154.00 & 1490.00 & 1524.00 & 2425.00 & 2239.00 & 2266.00 & 2216.00 & 1529.00 \\
\hline Thailand & 612.00 & 711.00 & 893.00 & 1682.00 & 1360.00 & 1280.00 & 831.00 & 372.00 \\
\hline Hong Kong & 3024.00 & 4297.00 & 5512.00 & 11888.00 & 8191.00 & 10073.00 & 13451.00 & 10722.00 \\
\hline Taiwan & 4350.00 & 4600.00 & 3377.00 & 6070.00 & 7111.00 & 5158.00 & 6933.00 & 8187.00 \\
\hline
\end{tabular}

Table 11. Stock market prices indexes (property sector)

$\begin{array}{lrrrrrrrr} & \mathbf{1 9 9 0} & \mathbf{1 9 9 1} & \mathbf{1 9 9 2} & \mathbf{1 9 9 3} & \mathbf{1 9 9 4} & \mathbf{1 9 9 5} & \mathbf{1 9 9 6} & \mathbf{1 9 9 7} \\ \text { Indonesia } & & & & & & & & \\ \text { Malaysia } & & 119.00 & 66.00 & 214.00 & 140.00 & 112.00 & 143.00 & 40.00 \\ \text { Philippines } & 113.00 & 113.00 & 126.00 & 369.00 & 240.00 & 199.00 & 294.00 & 64.00 \\ \text { Singapore } & 32.00 & 34.00 & 39.00 & 81.00 & 80.00 & 87.00 & 119.00 & 59.00 \\ \text { Thailand } & 230.00 & 280.00 & 250.00 & 541.00 & 548.00 & 614.00 & 648.00 & 357.00 \\ \text { Hong Kong } & 74.00 & 82.00 & 168.00 & 367.00 & 232.00 & 192.00 & 99.00 & 7.00 \\ \text { Taiwan } & 312.00 & 453.00 & 554.00 & 1392.00 & 862.00 & 1070.00 & 1682.00 & 941.00 \\ & 61.00 & 71.00 & 57.00 & 137.00 & 109.00 & 59.00 & 55.00 & 55.00\end{array}$


Table 12. Saving Rates (\% of GDP)

$\begin{array}{lcccccccc} & \mathbf{1 9 9 0} & \mathbf{1 9 9 1} & \mathbf{1 9 9 2} & \mathbf{1 9 9 3} & \mathbf{1 9 9 4} & \mathbf{1 9 9 5} & \mathbf{1 9 9 6} & \mathbf{1 9 9 7} \\ \text { Korea } & & & & & & & & \\ \text { Indonesia } & 35.69 & 35.74 & 34.88 & 34.91 & 34.60 & 35.14 & 33.60 & 33.06 \\ \text { Malaysia } & 31.75 & 31.10 & 33.41 & 28.66 & 29.52 & 27.65 & 27.50 & 27.98 \\ \text { Philippines } & 29.07 & 23.24 & 30.06 & 27.70 & 33.81 & 34.65 & 37.81 & 39.34 \\ \text { Singapore } & 17.85 & 17.76 & 18.16 & 17.29 & 20.32 & 17.16 & 19.35 & 18.77 \\ \text { Thailand } & 45.32 & 46.56 & 48.35 & 46.17 & 50.82 & 51.05 & 51.33 & 51.30 \\ \text { Hong Kong } & 32.33 & 34.83 & 33.73 & 34.26 & 33.89 & 33.25 & 33.22 & 32.64 \\ \text { China } & 35.85 & 33.78 & 33.76 & 35.67 & 33.83 & 31.94 & 29.95 & 31.33 \\ \text { Taiwan } & 37.77 & 37.84 & 37.26 & 41.29 & 42.04 & 40.22 & 39.25 & 41.15 \\ & 30.50 & 30.26 & 28.93 & 28.68 & 26.99 & 26.70 & 25.92 & 25.43\end{array}$

Table 13. Government Fiscal Balances (\% of GDP)

$\begin{array}{lrrrrrrrr} & \mathbf{1 9 9 0} & \mathbf{1 9 9 1} & \mathbf{1 9 9 2} & \mathbf{1 9 9 3} & \mathbf{1 9 9 4} & \mathbf{1 9 9 5} & \mathbf{1 9 9 6} & \mathbf{1 9 9 7} \\ \text { Korea } & & & & & & & & \\ \text { Indonesia } & -0.68 & -1.63 & -0.50 & 0.64 & 0.32 & 0.30 & 0.46 & 0.25 \\ \text { Malaysia } & 0.43 & 0.45 & -0.44 & 0.64 & 1.03 & 2.44 & 1.26 & 0.00 \\ \text { Philippines } & -3.10 & -2.10 & -0.89 & 0.23 & 2.44 & 0.89 & 0.76 & 2.52 \\ \text { Singapore } & -3.47 & -2.10 & -1.16 & -1.46 & 1.04 & 0.57 & 0.28 & 0.06 \\ \text { Thailand } & 10.53 & 8.58 & 12.35 & 15.67 & 11.93 & 13.07 & 14.10 & 9.52 \\ \text { China } & 4.59 & 4.79 & 2.90 & 2.13 & 1.89 & 2.94 & 0.97 & -0.32 \\ \text { Taiwan } & -0.79 & -1.09 & -0.97 & -0.85 & -1.22 & -1.00 & -0.82 & -0.75 \\ & 1.85 & -2.18 & -5.34 & -3.88 & -1.73 & -1.09 & -1.34 & -1.68\end{array}$

Table 14. Inflation Rate

\begin{tabular}{|c|c|c|c|c|c|c|c|c|}
\hline & & 1991 & 1992 & 1993 & 1994 & 1995 & 1996 & 1997 \\
\hline Korea & & 9.30 & 6.22 & 4.82 & 6.24 & 4.41 & 4.96 & 4.45 \\
\hline Indonesia & & 9.40 & 7.59 & 9.60 & 12.56 & 8.95 & 6.64 & 11.62 \\
\hline Malaysia & & 4.40 & 4.69 & 3.57 & 3.71 & 5.28 & 3.56 & 2.66 \\
\hline Philippines & & 18.70 & 8.93 & 7.58 & 9.06 & 8.11 & 8.41 & 5.01 \\
\hline Singapore & & 3.40 & 2.32 & 2.27 & 3.05 & 1.79 & 1.32 & 2.00 \\
\hline Thailand & & 5.70 & 4.07 & 3.36 & 5.19 & 5.69 & 5.85 & 5.61 \\
\hline Hong Kong & & 11.60 & 9.32 & 8.52 & 8.16 & 8.59 & 6.30 & 5.83 \\
\hline China & & 3.50 & 6.30 & 14.60 & 24.20 & 16.90 & 8.30 & 2.80 \\
\hline Taiwan & & 3.63 & 4.50 & 2.87 & 4.09 & 3.75 & 3.01 & 0.90 \\
\hline \multicolumn{9}{|c|}{ Table 15. Openness ((Exports+Imports)/2 as a \% of GDP) } \\
\hline & 1990 & 1991 & 1992 & 1993 & 1994 & 1995 & 1996 & 1997 \\
\hline Korea & 30.04 & 29.38 & 29.38 & 29.04 & 30.47 & 33.59 & 34.36 & 38.48 \\
\hline Indonesia & 26.30 & 27.18 & 28.23 & 25.26 & 25.94 & 26.98 & 26.13 & 28.22 \\
\hline Malaysia & 75.23 & 86.52 & 76.64 & 87.72 & 92.15 & 97.42 & 91.50 & 93.55 \\
\hline Philippines & 30.40 & 31.09 & 31.58 & 35.58 & 36.98 & 40.26 & 44.90 & 54.20 \\
\hline Thailand & 37.76 & 39.24 & 38.98 & 39.69 & 40.99 & 44.88 & 42.19 & 46.69 \\
\hline Hong Kong & 129.93 & 135.28 & 140.37 & 137.18 & 138.92 & 151.67 & 142.28 & 132.68 \\
\hline Taiwan & 44.27 & 45.14 & 42.34 & 43.29 & 43.16 & 47.80 & 46.63 & 48.07 \\
\hline
\end{tabular}


Table 16. Nominal Exchange Rate (to the US Dollar). Period average.

$\begin{array}{lrrrrrrrrr} & \mathbf{1 9 9 0} & \mathbf{1 9 9 1} & \mathbf{1 9 9 2} & \mathbf{1 9 9 3} & \mathbf{1 9 9 4} & \mathbf{1 9 9 5} & \mathbf{1 9 9 6} & \mathbf{1 9 9 7} & \mathbf{1 9 9 7 f} \\ \text { Korea } & & & & & & & & & \\ \text { Indonesia } & 707.76 & 733.35 & 780.65 & 802.67 & 803.45 & 771.27 & 804.45 & 951.29 & 1695.00 \\ \text { Malaysia } & 1842.80 & 1950.30 & 2029.90 & 2087.10 & 2160.80 & 2248.60 & 2342.30 & 2909.40 & 4650.00 \\ \text { Philippines } & 2.70 & 2.75 & 2.55 & 2.57 & 2.62 & 2.50 & 2.52 & 2.81 & 3.89 \\ \text { Singapore } & 24.31 & 27.48 & 25.51 & 27.12 & 26.42 & 25.71 & 26.22 & 29.47 & 39.98 \\ \text { Thailand } & 1.81 & 1.73 & 1.63 & 1.62 & 1.53 & 1.42 & 1.41 & 1.48 & 1.68 \\ \text { Hong Kong } & 25.59 & 25.52 & 25.40 & 25.32 & 25.15 & 24.91 & 25.34 & 31.36 & 47.25 \\ \text { China } & 7.79 & 7.77 & 7.74 & 7.74 & 7.73 & 7.74 & 7.73 & 7.74 & 7.75 \\ \text { Taiwan } & 4.78 & 5.32 & 5.51 & 5.76 & 8.62 & 8.35 & 8.31 & 8.29 & 8.28 \\ & 26.89 & 26.82 & 25.16 & 26.39 & 26.46 & 26.49 & 27.46 & 28.70 & 32.64\end{array}$

Table 17. Real Exchange Rate. End of year data.

$\begin{array}{lrrrrrrrr} & \mathbf{1 9 9 0} & \mathbf{1 9 9 1} & \mathbf{1 9 9 2} & \mathbf{1 9 9 3} & \mathbf{1 9 9 4} & \mathbf{1 9 9 5} & \mathbf{1 9 9 6} & \mathbf{1 9 9 7} \\ \text { Korea } & 96.00 & 91.50 & 87.70 & 85.20 & 84.70 & 87.70 & 87.20 & 58.60 \\ \text { Indonesia } & 97.40 & 99.60 & 100.80 & 103.80 & 101.00 & 100.50 & 105.40 & 62.40 \\ \text { Malaysia } & 97.00 & 96.90 & 109.70 & 111.00 & 107.10 & 106.90 & 112.10 & 84.90 \\ \text { Philippines } & 92.40 & 103.10 & 107.10 & 97.40 & 111.70 & 109.60 & 116.40 & 90.90 \\ \text { Singapore } & 101.20 & 105.70 & 106.00 & 108.60 & 111.90 & 112.70 & 118.20 & 114.40 \\ \text { Thailand } & 102.20 & 99.00 & 99.70 & 101.90 & 98.30 & 101.70 & 107.60 & 72.40 \\ \text { Hong Kong } & 99.70 & 103.90 & 108.50 & 116.00 & 114.50 & 116.00 & 125.80 & 138.40 \\ \text { Taiwan } & 96.50 & 95.70 & 95.70 & 91.40 & 92.60 & 90.40 & 89.60 & 89.20 \\ & & & & & & & & \end{array}$

Data Source: J.P. Morgan. The base figure (100) is the average for the year 1990.

Table 18. Bank Lending to Private Sector (\% growth)

$\begin{array}{lrrrrrrr} & \mathbf{1 9 9 1} & \mathbf{1 9 9 2} & \mathbf{1 9 9 3} & \mathbf{1 9 9 4} & \mathbf{1 9 9 5} & \mathbf{1 9 9 6} & \mathbf{1 9 9 7} \\ & & & & & & & \\ \text { Korea } & 20.78 & 12.55 & 12.94 & 20.08 & 15.45 & 20.01 & 21.95 \\ \text { Indonesia } & 17.82 & 12.29 & 25.48 & 22.97 & 22.57 & 21.45 & 46.42 \\ \text { Malaysia } & 20.58 & 10.79 & 10.80 & 16.04 & 30.65 & 25.77 & 26.96 \\ \text { Philippines } & 7.33 & 24.66 & 40.74 & 26.52 & 45.39 & 48.72 & 28.79 \\ \text { Singapore } & 12.41 & 9.77 & 15.15 & 15.25 & 20.26 & 15.82 & 12.68 \\ \text { Thailand } & 20.45 & 20.52 & 24.03 & 30.26 & 23.76 & 14.63 & 19.80 \\ \text { Hong Kong } & & 10.17 & 20.15 & 19.94 & 10.99 & 15.75 & 20.10 \\ \text { China } & 19.76 & 20.84 & 43.52 & 24.58 & 24.23 & 24.68 & 20.96 \\ \text { Taiwan } & 21.25 & 28.70 & 19.46 & 16.18 & 10.00 & 6.00 & 8.92\end{array}$

Table 19. Bank Lending to Private Sector (\% of GDP)

$\begin{array}{lrrrrrrrr} & \mathbf{1 9 9 0} & \mathbf{1 9 9 1} & \mathbf{1 9 9 2} & \mathbf{1 9 9 3} & \mathbf{1 9 9 4} & \mathbf{1 9 9 5} & \mathbf{1 9 9 6} & \mathbf{1 9 9 7} \\ \text { Korea } & & & & & & & & \\ \text { Indonesia } & 52.54 & 52.81 & 53.34 & 54.21 & 56.84 & 57.04 & 61.81 & 69.79 \\ \text { Malaysia } & 49.67 & 50.32 & 49.45 & 48.90 & 51.88 & 53.48 & 55.42 & 69.23 \\ \text { Philippines } & 71.36 & 75.29 & 74.72 & 74.06 & 74.61 & 84.80 & 93.39 & 106.91 \\ \text { Singapore } & 19.17 & 17.76 & 20.44 & 26.37 & 29.06 & 37.52 & 48.98 & 56.53 \\ \text { Thailand } & 82.20 & 83.34 & 85.06 & 84.14 & 84.21 & 90.75 & 95.96 & 100.29 \\ \text { Hong Kong } & 64.30 & 67.70 & 72.24 & 80.01 & 91.00 & 97.62 & 101.94 & 116.33 \\ \text { China } & & 141.84 & 134.20 & 140.02 & 149.00 & 155.24 & 162.36 & 174.24 \\ \text { Taiwan } & 85.51 & 87.87 & 86.17 & 95.49 & 87.12 & 85.83 & 91.65 & 101.07 \\ & 100.41 & 108.99 & 126.43 & 137.23 & 146.89 & 149.49 & 146.05 & 146.23\end{array}$


Table 20. Lending Boom Measure (rate of growth between 1990 and 1996 of the ratio between the claims on the private sector of the deposit money banks and nominal GDP).

$\begin{array}{lrlr}\text { Korea } & 11 \% & \text { Singapore } & 17 \% \\ \text { Indonesia } & 10 \% & \text { Thailand } & 58 \% \\ \text { Malaysia } & 31 \% & \text { Hong Kong } & 26 \% \\ \text { Philippines } & 151 \% & \text { China } & 7 \%\end{array}$

Table 21. Non-Performing Loans (as proportion of otal lending in 1996)

$\begin{array}{lrlr}\text { Korea } & 8 \% & \text { Thailand } & 13 \% \\ \text { Indonesia } & 13 \% & \text { Hong Kong } & 3 \% \\ \text { Malaysia } & 10 \% & \text { China } & 14 \% \\ \text { Philippines } & 14 \% & \text { Taiwan } & 4 \% \\ \text { Singapore } & 4 \% & & \end{array}$

Source: 1997 BIS Annual Report; Jardine Fleming.

Table 22. Banking System Exposure to Risk. (\% of assets at the end of 1997)

$\begin{array}{lllrrl} & \begin{array}{l}\text { Property } \\ \text { Exposure }\end{array} & \begin{array}{c}\text { Collateral } \\ \text { Valuation }\end{array} & \text { Non-Performing Loans } & \text { Capital } \\ \text { Korea } & 15-25 \% & 80-100 \% & 16 \% & \mathbf{1 9 9 8 f} & \text { Ratio } \\ \text { Indonesia } & 25-30 \% & 80-100 \% & 11 \% & 20.00 \% & 6-10 \% \\ \text { Malaysia } & 30-40 \% & 80-100 \% & 7.50 \% & 15.00 \% & 8-10 \% \\ \text { Philippines } & 15-20 \% & 70-80 \% & 5.50 \% & 7.00 \% & 8-14 \% \\ \text { Singapore } & 30-40 \% & 70-80 \% & 2.00 \% & 3.50 \% & 15-18 \% \\ \text { Thailand } & 30-40 \% & 80-100 \% & 15 \% & 25 \% & 6-10 \% \\ \text { Hong Kong } & 40-55 \% & 50-70 \% & 1.50 \% & 3 \% & 15-20 \%\end{array}$

Source: JP Morgan "Asian Financial Markets", January 1998.

Table 23. Foreign Debt, World Bank Data (as a \% of GDP)

$\begin{array}{lrrrrrrr} & \mathbf{1 9 9 0} & \mathbf{1 9 9 1} & \mathbf{1 9 9 2} & \mathbf{1 9 9 3} & \mathbf{1 9 9 4} & \mathbf{1 9 9 5} & \mathbf{1 9 9 6} \\ \text { Korea } & & & & & & & \\ \text { Indonesia } & 13.79 & 13.51 & 14.34 & 14.18 & 14.32 & 23.80 & 28.40 \\ \text { Malaysia } & 65.89 & 68.21 & 68.74 & 56.44 & 60.96 & 61.54 & 56.74 \\ \text { Philippines } & 35.80 & 35.48 & 34.51 & 40.74 & 40.40 & 39.31 & 40.06 \\ \text { Singapore } & 69.02 & 71.45 & 62.29 & 66.09 & 62.42 & 53.21 & 49.75 \\ \text { Thailand } & 11.23 & 11.07 & 9.47 & 9.45 & 10.79 & 9.84 & 10.74 \\ \text { Hong Kong } & 32.80 & 38.38 & 37.51 & 34.10 & 33.31 & 33.78 & 50.05 \\ \text { China } & 16.80 & 14.84 & 14.99 & 14.35 & 18.38 & 16.60 & 15.44 \\ \text { Taiwan } & 14.26 & 14.84 & 14.99 & 14.35 & 18.38 & 16.60 & 15.44 \\ & 11.04 & 10.73 & 9.37 & 10.44 & 10.87 & 10.40 & 10.07\end{array}$

Note: The source for Tables 23-27 is the Global Development Finance (GDF) report of the World Bank and IMF-IFS. The data for Hong Kong, Singapore, Taiwan in tables 23-24 and 26-27 are from the Asian Development Bank. The data for Korea in 1995 and 1996 (in italics) are from OECD, External Debt Statistics.

Table 24. Short-Term Debt, World Bank Data (\% of Total).

$\begin{array}{lrrrrrrr} & \mathbf{1 9 9 0} & \mathbf{1 9 9 1} & \mathbf{1 9 9 2} & \mathbf{1 9 9 3} & \mathbf{1 9 9 4} & \mathbf{1 9 9 5} & \mathbf{1 9 9 6} \\ \text { Korea } & & & & & & & \\ \text { Indonesia } & 30.87 & 28.19 & 26.99 & 25.85 & 25.47 & 51.60 & 50.20 \\ \text { Malaysia } & 15.92 & 18.00 & 20.52 & 20.17 & 18.05 & 20.87 & 24.98 \\ \text { Philippines } & 12.43 & 12.14 & 18.18 & 26.58 & 21.13 & 21.19 & 27.83 \\ \text { Singapore } & 14.48 & 15.24 & 15.93 & 14.01 & 14.29 & 13.38 & 19.34 \\ \text { Thailand } & 17.51 & 18.92 & 19.91 & 17.87 & 13.28 & 14.56 & 19.81 \\ \text { Hong Kong } & 29.63 & 33.13 & 35.22 & 53.01 & 60.67 & 72.36 & 41.41 \\ \text { China } & 45.97 & 46.63 & 45.89 & 41.19 & 30.04 & 28.36 & 43.57 \\ \text { Taiwan } & 16.85 & 17.89 & 19.01 & 17.80 & 17.40 & 18.91 & 19.72 \\ & 88.31 & 86.49 & 86.93 & 84.99 & 76.75 & 72.18 & 68.44\end{array}$


Table 25. Debt Service as a Ratio of Exports. World Bank Data

$\begin{array}{lrrrrrrr} & \mathbf{1 9 9 0} & \mathbf{1 9 9 1} & \mathbf{1 9 9 2} & \mathbf{1 9 9 3} & \mathbf{1 9 9 4} & \mathbf{1 9 9 5} & \mathbf{1 9 9 6} \\ \text { Korea } & & & & & & & \\ \text { Indonesia } & 10.80 & 7.20 & 7.80 & 9.40 & 6.90 & 7.30 & 8.80 \\ \text { Malaysia } & 33.40 & 34.30 & 32.60 & 33.60 & 30.70 & 30.90 & 36.80 \\ \text { Philippines } & 12.60 & 7.40 & 9.10 & 8.40 & 9.00 & 7.00 & 8.20 \\ \text { Thailand } & 27.00 & 23.00 & 24.40 & 25.60 & 18.90 & 16.40 & 13.70 \\ \text { Hong Kong } & 16.90 & 13.00 & 13.80 & 13.70 & 13.50 & 11.60 & 11.50 \\ \text { China } & 1.71 & 1.23 & 1.08 & 0.93 & 1.49 & 0.71 & \\ \text { Taiwan } & 11.70 & 11.90 & 10.20 & 11.10 & 8.90 & 9.90 & 8.70 \\ & 2.29 & 2.01 & 1.86 & 1.33 & 1.68 & 1.82 & \end{array}$

Table 26. Short-Term Debt, World Bank Data (\% of foreign reserves)

$\begin{array}{lrrrrrrr} & \mathbf{1 9 9 0} & \mathbf{1 9 9 1} & \mathbf{1 9 9 2} & \mathbf{1 9 9 3} & \mathbf{1 9 9 4} & \mathbf{1 9 9 5} & \mathbf{1 9 9 6} \\ \text { Korea } & & & & & & & \\ \text { Indonesia } & 72.13 & 81.75 & 69.62 & 60.31 & 54.06 & 171.45 & 203.23 \\ \text { Malaysia } & 149.28 & 154.62 & 172.81 & 159.70 & 160.36 & 189.42 & 176.59 \\ \text { Philippines } & 19.54 & 19.05 & 21.12 & 25.51 & 24.34 & 30.60 & 40.98 \\ \text { Singapore } & 479.11 & 152.31 & 119.37 & 107.68 & 95.00 & 82.85 & 79.45 \\ \text { Thailand } & 2.65 & 2.67 & 2.35 & 2.04 & 1.75 & 1.78 & 2.60 \\ \text { Hong Kong } & 62.55 & 71.31 & 72.34 & 92.49 & 99.48 & 114.21 & 99.69 \\ \text { China } & 23.52 & 21.78 & 18.38 & 17.09 & 16.49 & 14.16 & 22.35 \\ \text { Taiwan } & 31.49 & 24.68 & 66.76 & 68.33 & 33.04 & 29.62 & 23.74 \\ & 21.56 & 20.21 & 21.00 & 23.64 & 21.76 & 21.64 & 21.31\end{array}$

Table 27. Debt Service plus Short-Term Debt, World Bank Data (\% of foreign reserves ).

$\begin{array}{lrrrrrrr} & \mathbf{1 9 9 0} & \mathbf{1 9 9 1} & \mathbf{1 9 9 2} & \mathbf{1 9 9 3} & \mathbf{1 9 9 4} & \mathbf{1 9 9 5} & \mathbf{1 9 9 6} \\ \text { Korea } & 127.43 & 125.90 & 110.35 & 105.66 & 84.90 & 204.93 & 243.31 \\ \text { Indonesia } & 282.92 & 278.75 & 292.03 & 284.79 & 277.95 & 309.18 & 294.17 \\ \text { Malaysia } & 63.96 & 45.87 & 45.55 & 42.37 & 48.73 & 55.92 & 69.33 \\ \text { Philippines } & 867.64 & 256.99 & 217.08 & 212.60 & 171.98 & 166.60 & 137.06 \\ \text { Thailand } & 102.35 & 99.34 & 101.34 & 120.28 & 126.54 & 138.13 & 122.62 \\ \text { Hong Kong } & 30.51 & 26.87 & 22.82 & 20.64 & 22.02 & 16.82 & \\ \text { China } & 55.34 & 43.70 & 108.55 & 113.74 & 54.08 & 49.61 & 38.46 \\ \text { Taiwan } & 23.92 & 22.29 & 23.08 & 25.21 & 23.69 & 24.20 & \end{array}$

Table 28. Foreign Liabilities and Assets (toward BIS Reporting Banks) (US \$ billion)

$\begin{array}{lrrrrrrrr}\text { Korea } & \mathbf{1 9 9 3} & \mathbf{1 9 9 4} & \mathbf{1 9 9 5} & \mathbf{1 9 9 6} & \mathbf{1 9 9 7} & \mathbf{1 9 9 7 - Q 1} & \mathbf{1 9 9 7 - Q 2} & \mathbf{1 9 9 7 - Q 4} \\ \text { Foreign Liabilities } & 45.22 & 60.97 & 83.26 & 109.15 & 103.78 & 113.42 & 118.25 & 104.71 \\ \text { Foreign Assets } & 15.20 & 20.54 & 25.10 & 29.07 & 41.28 & 33.04 & 35.87 & 41.79 \\ \text { Net Liabilities } & 30.02 & 40.43 & 58.16 & 80.08 & 62.50 & 80.39 & 82.38 & 62.92 \\ \text { Foreign Liabilities (non-banks) } & 10.59 & 13.49 & 17.91 & 24.07 & 25.18 & 25.98 & 26.53 & 25.40 \\ \text { Foreign Assets (non-banks) } & 1.45 & 2.29 & 3.58 & 3.47 & 2.24 & 3.42 & 3.06 & 2.28 \\ \text { Net Liabilities } & 9.14 & 11.20 & 14.33 & 20.61 & 22.94 & 22.57 & 23.46 & 23.13 \\ \text { Foreign Liabilities (banks) } & 34.63 & 47.49 & 65.35 & 85.08 & 78.60 & 87.44 & 91.72 & 79.31 \\ \text { Foreign Assets (banks) } & 13.75 & 18.25 & 21.52 & 25.61 & 39.04 & 29.62 & 32.80 & 39.52 \\ \text { Net Liabilities } & 20.88 & 29.24 & 43.83 & 59.47 & 39.56 & 57.82 & 58.92 & 39.79 \\ & & & & & & & & \\ \text { Indonesia } & 1993 & 1994 & 1995 & 1996 & 1997 & 1997-\mathbf{Q 1} & \mathbf{1 9 9 7 - Q 2} & \mathbf{1 9 9 7 - Q 4} \\ \text { Foreign Liabilities } & 37.20 & 41.62 & 48.93 & 57.85 & 62.76 & 59.65 & 62.44 & 63.58 \\ \text { Foreign Assets } & 12.58 & 10.39 & 11.48 & 13.64 & 11.55 & 12.75 & 11.20 & 11.92 \\ \text { Net Liabilities } & 24.63 & 31.23 & 37.45 & 44.21 & 51.21 & 46.91 & 51.24 & 51.66 \\ \text { Foreign Liabilities (non-banks) } & 22.23 & 24.57 & 27.93 & 34.36 & 38.70 & 36.17 & 37.62 & 39.35 \\ \text { Foreign Assets (non-banks) } & 3.61 & 2.47 & 2.56 & 2.68 & 3.32 & 2.90 & 2.71 & 3.37 \\ \text { Net Liabilities } & 18.63 & 22.11 & 25.37 & 31.69 & 35.37 & 33.27 & 34.91 & 35.98 \\ \text { Foreign Liabilities (banks) } & 14.97 & 17.05 & 21.00 & 23.49 & 24.07 & 23.48 & 24.82 & 24.23 \\ \text { Foreign Assets (banks) } & 8.97 & 7.92 & 8.93 & 10.97 & 8.23 & 9.85 & 8.49 & 8.55 \\ \text { Net Liabilities } & 6.00 & 9.13 & 12.08 & 12.52 & 15.84 & 13.63 & 16.33 & 15.68\end{array}$




\begin{tabular}{|c|c|c|c|c|c|c|c|c|}
\hline Malaysia & 1993 & 1994 & 1995 & 1996 & 1997 & 1997-Q1 & 1997-Q2 & 1997-Q4 \\
\hline Foreign Liabilities & 16.02 & 14.48 & 18.76 & 25.91 & 29.08 & 31.23 & 33.00 & 29.47 \\
\hline Foreign Assets & 19.24 & 10.32 & 13.03 & 17.49 & 13.07 & 18.88 & 17.47 & 13.93 \\
\hline Net Liabilities & -3.21 & 4.15 & 5.72 & 8.41 & 16.01 & 12.35 & 15.53 & 15.54 \\
\hline Foreign Liabilities (non-banks) & 4.26 & 3.91 & 5.54 & 6.92 & 6.46 & 7.06 & 7.50 & 6.70 \\
\hline Foreign Assets (non-banks) & 1.94 & 2.12 & 2.58 & 2.75 & 3.46 & 3.49 & 3.03 & 3.51 \\
\hline Net Liabilities & 2.31 & 1.79 & 2.96 & 4.17 & 3.00 & 3.57 & 4.47 & 3.20 \\
\hline Foreign Liabilities (banks) & 11.77 & 10.57 & 13.22 & 18.99 & 22.62 & 24.17 & 25.50 & 22.76 \\
\hline Foreign Assets (banks) & 17.29 & 8.21 & 10.46 & 14.74 & 9.61 & 15.39 & 14.44 & 10.42 \\
\hline Net Liabilities & -5.53 & 2.36 & 2.76 & 4.25 & 13.01 & 8.78 & 11.06 & 12.35 \\
\hline Philippines & 1993 & 1994 & 1995 & 1996 & 1997 & 1997-Q1 & 1997-Q2 & 1997-Q4 \\
\hline Foreign Liabilities & 6.61 & 6.54 & 8.07 & 13.51 & 16.61 & 15.11 & 17.02 & 16.79 \\
\hline Foreign Assets & 5.81 & 6.75 & 7.34 & 7.84 & 9.70 & 8.59 & 7.68 & 9.84 \\
\hline Net Liabilities & 0.80 & -0.21 & 0.73 & 5.67 & 6.91 & 6.52 & 9.34 & 6.96 \\
\hline Foreign Liabilities (non-banks) & 3.37 & 2.84 & 3.12 & 4.15 & 6.34 & 4.82 & 5.24 & 6.42 \\
\hline Foreign Assets (non-banks) & 2.96 & 3.22 & 3.31 & 3.06 & 3.14 & 3.15 & 3.30 & 3.17 \\
\hline Net Liabilities & 0.42 & -0.37 & -0.19 & 1.09 & 3.20 & 1.68 & 1.94 & 3.25 \\
\hline Foreign Liabilities (banks) & 3.24 & 3.70 & 4.95 & 9.36 & 10.27 & 10.28 & 11.78 & 10.37 \\
\hline Foreign Assets (banks) & 2.85 & 3.53 & 4.03 & 4.78 & 6.56 & 5.45 & 4.38 & 6.67 \\
\hline Net Liabilities & 0.39 & 0.17 & 0.92 & 4.58 & 3.72 & 4.84 & 7.40 & 3.71 \\
\hline Singapore & 1993 & 1994 & 1995 & 1996 & 1997 & 1997-Q1 & 1997-Q2 & 1997-Q4 \\
\hline Foreign Liabilities & 233.39 & 248.00 & 282.03 & 287.24 & 295.83 & 293.41 & 306.89 & 310.24 \\
\hline Foreign Assets & 155.02 & 153.43 & 170.26 & 177.83 & 214.65 & 193.06 & 202.33 & 219.64 \\
\hline Net Liabilities & 78.37 & 94.57 & 111.77 & 109.42 & 81.18 & 100.35 & 104.56 & 90.59 \\
\hline Foreign Liabilities (non-banks) & 3.73 & 4.05 & 5.65 & 6.71 & 8.01 & 8.22 & 8.41 & 8.13 \\
\hline Foreign Assets (non-banks) & 9.56 & 10.88 & 12.07 & 13.62 & 14.16 & 13.72 & 13.77 & 14.38 \\
\hline Net Liabilities & -5.82 & -6.83 & -6.43 & -6.91 & -6.16 & -5.50 & -5.36 & -6.26 \\
\hline Foreign Liabilities (banks) & 229.66 & 243.95 & 276.38 & 280.53 & 287.82 & 285.18 & 298.49 & 302.11 \\
\hline Foreign Assets (banks) & 145.47 & 142.55 & 158.19 & 164.21 & 200.49 & 179.34 & 188.56 & 205.26 \\
\hline Net Liabilities & 84.19 & 101.40 & 118.19 & 116.32 & 87.33 & 105.85 & 109.92 & 96.85 \\
\hline Thailand & 1993 & 1994 & 1995 & 1996 & 1997 & 1997-Q1 & 1997-Q2 & 1997-Q4 \\
\hline Foreign Liabilities & 34.73 & 54.44 & 92.18 & 99.27 & 79.66 & 99.82 & 99.54 & 81.82 \\
\hline Foreign Assets & 5.01 & 7.04 & 11.81 & 9.00 & 9.81 & 10.09 & 8.78 & 9.95 \\
\hline Net Liabilities & 29.72 & 47.40 & 80.37 & 90.27 & 69.84 & 89.73 & 90.76 & 71.86 \\
\hline Foreign Liabilities (non-banks) & 9.14 & 9.81 & 12.56 & 14.13 & 12.00 & 13.84 & 13.50 & 12.23 \\
\hline Foreign Assets (non-banks) & 1.63 & 1.84 & 2.13 & 1.90 & 2.06 & 1.91 & 2.02 & 2.09 \\
\hline Net Liabilities & 7.50 & 7.97 & 10.43 & 12.22 & 9.94 & 11.92 & 11.49 & 10.14 \\
\hline Foreign Liabilities (banks) & 25.59 & 44.63 & 79.62 & 85.15 & 67.66 & 85.98 & 86.04 & 69.59 \\
\hline Foreign Assets (banks) & 3.38 & 5.20 & 9.68 & 7.10 & 7.75 & 8.17 & 6.76 & 7.86 \\
\hline Net Liabilities & 22.22 & 39.43 & 69.94 & 78.05 & 59.90 & 77.81 & 79.28 & 61.73 \\
\hline Hong Kong & 1993 & 1994 & 1995 & 1996 & 1997 & 1997-Q1 & 1997-Q2 & 1997-Q4 \\
\hline Foreign Liabilities & 412.99 & 493.96 & 513.04 & 469.96 & 469.58 & 480.55 & 502.90 & 499.74 \\
\hline Foreign Assets & 290.01 & 345.19 & 329.74 & 284.37 & 294.76 & 302.24 & 296.81 & 302.72 \\
\hline Net Liabilities & 122.98 & 148.77 & 183.31 & 185.60 & 174.83 & 178.31 & 206.09 & 197.02 \\
\hline Foreign Liabilities (non-banks) & 19.61 & 17.90 & 22.58 & 26.73 & 20.69 & 25.48 & 26.10 & 21.44 \\
\hline Foreign Assets (non-banks) & 49.41 & 53.08 & 54.28 & 60.47 & 64.34 & 63.02 & 63.53 & 65.04 \\
\hline Net Liabilities & -29.80 & -35.18 & -31.70 & -33.74 & -43.66 & -37.54 & -37.43 & -43.60 \\
\hline Foreign Liabilities (banks) & 393.38 & 476.06 & 490.46 & 443.24 & 448.90 & 455.08 & 476.79 & 478.31 \\
\hline Foreign Assets (banks) & 240.60 & 292.11 & 275.46 & 223.90 & 230.42 & 239.22 & 233.27 & 237.68 \\
\hline Net Liabilities & 152.78 & 183.95 & 215.00 & 219.34 & 218.48 & 215.86 & 243.52 & 240.63 \\
\hline China & 1993 & 1994 & 1995 & 1996 & 1997 & 1997-Q1 & 1997-Q2 & 1997-Q4 \\
\hline Foreign Liabilities & 48.59 & 56.46 & 67.06 & 79.75 & 90.08 & 82.18 & 86.33 & 91.20 \\
\hline Foreign Assets & 49.16 & 59.95 & 57.43 & 66.54 & 66.40 & 64.58 & 64.99 & 67.04 \\
\hline Net Liabilities & -0.57 & -3.49 & 9.63 & 13.21 & 23.68 & 17.60 & 21.34 & 24.15 \\
\hline Foreign Liabilities (non-banks) & 13.30 & 15.18 & 16.10 & 17.88 & 18.12 & 17.95 & 18.90 & 18.36 \\
\hline Foreign Assets (non-banks) & 2.50 & 2.73 & 2.92 & 3.00 & 3.79 & 3.70 & 3.98 & 3.86 \\
\hline Net Liabilities & 10.81 & 12.46 & 13.17 & 14.88 & 14.33 & 14.26 & 14.93 & 14.51 \\
\hline
\end{tabular}


Foreign Liabilities (banks)

Foreign Assets (banks)

Net Liabilities

Taiwan

Foreign Liabilities

Foreign Assets

Net Liabilities

Foreign Liabilities (non-banks)

Foreign Assets (non-banks)

Net Liabilities

Foreign Liabilities (banks)

Foreign Assets (banks)

Net Liabilities

$\begin{array}{rrrrrrrr}35.29 & 41.28 & 50.96 & 61.87 & 71.96 & 64.22 & 67.43 & 72.83 \\ 46.67 & 57.23 & 54.51 & 63.54 & 62.60 & 60.88 & 61.01 & 63.19 \\ -11.38 & -15.94 & -3.54 & -1.67 & 9.36 & 3.34 & 6.42 & 9.65 \\ & & & & & & & \\ & & 1995 & \mathbf{1 9 9 6} & \mathbf{1 9 9 7} & \mathbf{1 9 9 7 - Q 1} & \mathbf{1 9 9 7 - Q 2} & \mathbf{1 9 9 7 - Q 4} \\ & 22.13 & 22.79 & 22.43 & 24.69 & 25.23 & 22.66 \\ & & 36.03 & 37.48 & 36.46 & 37.37 & 36.23 & 37.27 \\ & -13.90 & -14.69 & -14.04 & -12.68 & -11.00 & -14.61 \\ & 2.51 & 2.97 & 3.13 & 3.53 & 3.19 & 3.19 \\ & 7.28 & 8.22 & 9.03 & 8.30 & 8.34 & 9.10 \\ & -4.77 & -5.25 & -5.90 & -4.77 & -5.15 & -5.92 \\ & 19.63 & 19.82 & 19.29 & 21.16 & 22.04 & 19.47 \\ & 28.76 & 29.27 & 27.44 & 29.07 & 27.89 & 28.16 \\ & -9.13 & -9.44 & -8.14 & -7.91 & -5.85 & -8.69\end{array}$

Source: Bank of International Settlements (BIS): International Banking and Financial Market Developments

Table 29. Liabilities towards BIS Banks (\% of GDP)

$\begin{array}{lrrrrr} & 1993 & 1994 & 1995 & 1996 & 1997 \\ \text { Korea } & & & & & \\ \text { Indonesia } & 13.59 & 16.01 & 18.24 & 22.52 & 23.45 \\ \text { Malaysia } & 23.54 & 23.53 & 24.21 & 25.44 & 29.25 \\ \text { Philippines } & 24.96 & 19.97 & 21.48 & 26.10 & 29.53 \\ \text { Singapore } & 12.16 & 10.21 & 10.88 & 16.31 & 20.20 \\ \text { Thailand } & 400.24 & 349.10 & 330.15 & 305.37 & 307.16 \\ \text { Hong Kong } & 27.73 & 37.71 & 54.82 & 54.71 & 51.75 \\ \text { China } & 356.15 & 377.60 & 368.51 & 304.94 & 272.53 \\ \text { Taiwan } & 8.12 & 10.33 & 9.43 & 9.56 & 9.82 \\ & 9.60 & 9.29 & 8.08 & 8.04 & 7.29\end{array}$

Table 30. Consolidated cross-border claims in all currencies and local claims

in non-local currencies. (Mid-1997 figures. Shares of various sectors and total stock)

$\begin{array}{lllll} & \text { Banks } & \begin{array}{l}\text { Public } \\ \text { Sector }\end{array} & \begin{array}{l}\text { Non-Bank Private } \\ \text { Sector }\end{array} & \begin{array}{l}\text { Total in billions of } \\ \text { US dollars }\end{array} \\ \text { Korea } & 44.0 \% & 7.4 \% & 48.5 \% & 103.4 \\ \text { Indonesia } & 21.1 \% & 11.1 \% & 67.7 \% & 58.7 \\ \text { Malaysia } & 36.4 \% & 6.4 \% & 57.1 \% & 28.8 \\ \text { Thailand } & 37.6 \% & 2.8 \% & 59.5 \% & 69.4 \\ \text { China } & 42.6 \% & 13.2 \% & 44.1 \% & 57.9 \\ \text { Taiwan } & 61.6 \% & 1.6 \% & 36.8 \% & 25.2\end{array}$

Note: Source for Tables $30-32$ and 36 is the Bank of International Settlements.

Table 31. Ratio of Liabilities to Assets (towards BIS Banks)

$\begin{array}{lrrrrr} & \mathbf{1 9 9 3} & \mathbf{1 9 9 4} & \mathbf{1 9 9 5} & \mathbf{1 9 9 6} & \mathbf{1 9 9 7} \\ \text { Korea } & & & & & \\ \text { Indonesia } & 2.97 & 2.97 & 3.32 & 3.75 & 2.51 \\ \text { Malaysia } & 2.96 & 4.01 & 4.26 & 4.24 & 5.43 \\ \text { Philippines } & 0.83 & 1.40 & 1.44 & 1.48 & 2.23 \\ \text { Singapore } & 1.14 & 0.97 & 1.10 & 1.72 & 1.71 \\ \text { Thailand } & 1.51 & 1.62 & 1.66 & 1.62 & 1.38 \\ \text { Hong Kong } & 6.93 & 7.73 & 7.81 & 11.03 & 8.12 \\ \text { China } & 1.42 & 1.43 & 1.56 & 1.65 & 1.59 \\ \text { Taiwan } & 0.99 & 0.94 & 1.17 & 1.20 & 1.36 \\ & 0.64 & 0.59 & 0.61 & 0.61 & 0.62\end{array}$


Table 32. Short-Term Liabilities towards BIS Banks (\% of total liabilities at the end of 1996)

$\begin{array}{llll}\text { Korea } & 67 \% & \text { Thailand } & 65 \% \\ \text { Indonesia } & 61 \% & \text { Hong Kong } & 82 \% \\ \text { Malaysia } & 50 \% & \text { China } & 49 \% \\ \text { Philippines } & 58 \% & \text { Taiwan } & 84 \% \\ \text { Singapore } & 92 \% & & \end{array}$

Table 33: Foreign Reserves (in months of imports)

$\begin{array}{lrrrrrrrr} & \mathbf{1 9 9 0} & \mathbf{1 9 9 1} & \mathbf{1 9 9 2} & \mathbf{1 9 9 3} & \mathbf{1 9 9 4} & \mathbf{1 9 9 5} & \mathbf{1 9 9 6} & \mathbf{1 9 9 7} \\ \text { Korea } & & & & & & & & \\ \text { Indonesia } & 2.34 & 1.83 & 2.23 & 2.53 & 2.63 & 2.52 & 2.32 & 1.42 \\ \text { Malaysia } & 3.24 & 3.53 & 3.62 & 3.60 & 3.24 & 2.94 & 3.64 & 3.26 \\ \text { Philippines } & 3.68 & 2.98 & 4.71 & 5.64 & 4.53 & 3.29 & 3.59 & 2.73 \\ \text { Thailand } & 0.75 & 2.63 & 2.93 & 2.59 & 2.81 & 2.33 & 2.95 & 1.79 \\ \text { Hong Kong } & 4.49 & 5.03 & 5.35 & 5.64 & 5.65 & 5.35 & 5.53 & 4.40 \\ \text { Taiwan } & 3.13 & 3.04 & 3.04 & 3.33 & 3.27 & 3.10 & 3.47 & 4.80 \\ & 12.99 & 12.86 & 11.28 & 10.64 & 10.90 & 8.90 & 8.68 & 7.56\end{array}$

Table 34. M1 to Foreign Reserves Ratio

$\begin{array}{lrrrrrrrr} & \mathbf{1 9 9 0} & \mathbf{1 9 9 1} & \mathbf{1 9 9 2} & \mathbf{1 9 9 3} & \mathbf{1 9 9 4} & \mathbf{1 9 9 5} & \mathbf{1 9 9 6} & \mathbf{1 9 9 7} \\ \text { Korea } & 1.50 & 2.16 & 1.84 & 1.79 & 1.57 & 1.54 & 1.44 & 1.81 \\ \text { Indonesia } & 1.73 & 1.48 & 1.30 & 1.44 & 1.58 & 1.53 & 1.21 & 1.62 \\ \text { Malaysia } & 0.96 & 0.93 & 0.81 & 0.69 & 0.84 & 1.07 & 1.16 & 1.46 \\ \text { Philippines } & 4.14 & 1.21 & 1.05 & 1.13 & 1.01 & 1.19 & 0.89 & 1.24 \\ \text { Singapore } & 0.30 & 0.28 & 0.28 & 0.29 & 0.26 & 0.26 & 0.25 & 0.26 \\ \text { Thailand } & 0.57 & 0.50 & 0.48 & 0.48 & 0.47 & 0.43 & 0.44 & 0.52 \\ \text { Hong Kong } & & 0.45 & 0.46 & 0.45 & 0.40 & 0.35 & 0.35 & 0.23 \\ \text { China } & 4.95 & 3.87 & 10.30 & 12.99 & 4.72 & 4.07 & 3.45 & 3.24 \\ \text { Taiwan } & 0.99 & 0.98 & 1.18 & 1.27 & 1.28 & 1.32 & 1.42 & 1.55\end{array}$

Table 35. M2 to Foreign Reserves Ratio

$\begin{array}{lrrrrrrrr} & \mathbf{1 9 9 0} & \mathbf{1 9 9 1} & \mathbf{1 9 9 2} & \mathbf{1 9 9 3} & \mathbf{1 9 9 4} & \mathbf{1 9 9 5} & \mathbf{1 9 9 6} & \mathbf{1 9 9 7} \\ \text { Korea } & 6.48 & 8.33 & 7.20 & 6.91 & 6.45 & 6.11 & 6.51 & 10.50 \\ \text { Indonesia } & 6.16 & 5.51 & 5.61 & 6.09 & 6.55 & 7.09 & 6.50 & 7.37 \\ \text { Malaysia } & 2.91 & 2.99 & 2.64 & 2.09 & 2.47 & 3.33 & 3.66 & 4.99 \\ \text { Philippines } & 16.33 & 4.82 & 4.35 & 4.90 & 4.86 & 5.86 & 4.50 & 6.97 \\ \text { Singapore } & 1.23 & 1.18 & 1.17 & 1.05 & 1.06 & 1.05 & 1.03 & 1.17 \\ \text { Thailand } & 4.49 & 4.10 & 4.10 & 4.05 & 3.84 & 3.69 & 3.90 & 5.29 \\ \text { Hong Kong } & & 5.43 & 4.84 & 4.54 & 4.43 & 4.35 & 4.25 & 3.18 \\ \text { China } & 10.37 & 8.00 & 21.39 & 26.93 & 10.29 & 9.65 & 8.55 & 7.76 \\ \text { Taiwan } & 3.20 & 3.36 & 4.28 & 4.61 & 4.78 & 5.35 & 5.78 & 6.30\end{array}$

Table 36. Short-Term Liabilities towards BIS Banks (\% of foreign reserves, end of 1996)

$\begin{array}{lrlr}\text { Korea } & 213 \% & \text { Philippines } & 77 \% \\ \text { Indonesia } & 181 \% & \text { Thailand } & 169 \% \\ \text { Malaysia } & 47 \% & \text { China } & 36 \%\end{array}$


Table 37. Contribution of Inward FDI to Current Account Financing (\% of current account deficit)

$\begin{array}{lrrrrrrrr} & \mathbf{1 9 9 0} & \mathbf{1 9 9 1} & \mathbf{1 9 9 2} & \mathbf{1 9 9 3} & \mathbf{1 9 9 4} & \mathbf{1 9 9 5} & \mathbf{1 9 9 6} & \mathbf{1 9 9 7} \\ \text { Korea } & & & & & & & & \\ \text { Indonesia } & 45.16 & 14.19 & 18.43 & -59.39 & 20.92 & 20.88 & 10.11 & 34.82 \\ \text { Malaysia } & 36.58 & 34.79 & 63.92 & 95.16 & 75.54 & 67.58 & 80.83 & 97.11 \\ \text { Philippines } & 268.05 & 95.58 & 239.18 & 180.13 & 98.27 & 90.10 & 110.84 & 139.28 \\ \text { Thailand } & 19.67 & 52.61 & 22.80 & 41.05 & 53.93 & 74.65 & 38.38 & 29.12 \\ & 33.57 & 26.60 & 33.52 & 28.35 & 16.90 & 15.26 & 15.90 & 103.84\end{array}$

Table 38. Growth of Foreign Reserves in U.S. Dollars (\% growth rate, 1990-1996)

$\begin{array}{llll}\text { Korea } & 127 \% & \text { Singapore } & 176 \% \\ \text { Indonesia } & 144 \% & \text { Thailand } & 183 \% \\ \text { Malaysia } & 176 \% & \text { Hong Kong } & 159 \% \\ \text { Philippines } & 985 \% & \text { China } & 261 \%\end{array}$

